\title{
Quaternary fault activity in the SW Pannonian Basin: GPR surveying in Bilogora (NE Croatia)
}

\author{
Bojan MATOŠ ${ }^{1, *}$, Marjana ZAJC ${ }^{2}$, Branko KORDIĆ ${ }^{3}$, Bruno TOMLJENOVIĆ ${ }^{1}$ and Andrej GOSAR ${ }^{2}$ \\ 1 University of Zagreb, Faculty of Mining, Geology and Petroleum Engineering, Department of Geology and Geological \\ Engineering, Pierottijeva 6, 10000 Zagreb, Croatia \\ 2 University of Ljubljana Faculty of Natural Sciences and Engineering, Aškerčeva c. 12, 1000 Ljubljana, Slovenia \\ 3 University of Zagreb, Faculty of Geodesy, Kačićeva 26, 10000 Zagreb, Croatia
}

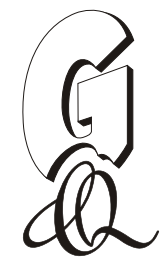

\begin{abstract}
Matoš, B., Zajc, M., Kordić, B., Tomljenović, B., Gosar, A., 2017. Quaternary fault activity in the SW Pannonian Basin: GPR surveying in Bilogora (NE Croatia). Geological Quarterly, 61 (1): 19-38, doi: 10.7306/gq.1308

In areas experiencing low deformation rates, landscapes provide limited evidence of ongoing tectonic activity, being either masked or altered by exogenic processes. Accordingly, the identification of fault activity and near surface deformation is commonly accomplished by multidisciplinary research combining geological, geophysical and geomorphic methods. In this study, Quaternary fault activity in the SW Pannonian Basin is investigated in the region of Bilogora, NE Croatia. The study area is positioned along the SW margin of the Drava Depression that was uplifted during the Pliocene and Quaternary within the Drava Depression Boundary Fault Zone. In this fault zone six GPR profiles were recorded. Reflection patterns, radar facies and truncations determined fault activity and near-surface deformation at four locations with vertical displacements of $\leq 1 \mathrm{~m}$. At two sites, profiles did not show truncation of the shallowest reflections, however, an elevation difference of ca. $10 \mathrm{~m}$ between two palaeostream channels along one of the profiles suggests Quaternary uplift accommodated by a mapped fault. Considering the importance of the seismogenic potential of active faults and their correlation with the seismicity of Bilogora, this research will be followed by additional studies of near-surface strata deformation and palaeoseismological fault properties.
\end{abstract}

Key words: GPR, Quaternary, SW Pannonian Basin, NE Croatia, Bilogora, neotectonics.

\section{INTRODUCTION}

Landscapes with geomorphic features characterized by specific drainage network patterns often provide initial evidence of recent tectonic activity in response to the movement and displacement along active faults (Patidar et al., 2007 and references therein). Fault surface expressions, dominated by either lateral or vertical displacements, usually are modified by burial or erosion that often, in low-deformation areas, are masked or may not be preserved (McClymont et al., 2009). Without these potentially important indicators that address how a fault rupture manifests at the surface, fault activity is usually observed by seismicity, i.e. historical and instrumental earthquake records. Besides fault dynamic stage associated with seismic cycles, identification of active segments, seismogenic properties, fault hazards and risks are effectively investigated by geomorphic mapping, palaeoseismology and shallow subsurface investigations that provide insight into near-surface structures, usually

\section{* Corresponding author, e-mail: bojan.matos@rgn.hr}

Received: October 30, 2015; accepted: April 5, 2016; first published online: August 29, 2016 not visible at the surface (Anderson et al., 2003; Neal, 2004; Patidar et al., 2007; McClymont et al., 2009).

In this work, our primary objective is to present results of the imaging of shallow subsurface structural deformation that can be associated to Quaternary fault activity. Imaging was performed by Ground Penetrating Radar (GPR) profiling. We used GPR profiling due to its efficiency and non-destructive nature that gave us an opportunity to correlate results of interpreted structures with the landscape morphology, depositional features, recent active fault strands, and fault-produced scarps or fault-related folds.

The area of Bilogora presented in this work is located in NE Croatia, within the NW-SE striking Drava Depression Boundary Fault Zone (DDBFZ) that delineates the SW margin of the Drava Depression (Fig. 1). The tectonic uplift of Bilogora along the DDBFZ started during Pliocene to Quaternary time (Prelogović et al., 1969, 1998; Kranjec et al., 1971; Prelogović, 1974; Prelogović and Velić, 1988, 1992), and, according to Babić et al. (1978) and Hećimović (1987), the final uplift stage commenced during late Middle Pleistocene to Holocene time. With vertical displacement of between ca. 300 and 550 m during the late Middle Pleistocene, the oldest Lower to Middle Pleistocene Drava River terrace in the Bilogora area was tectonically uplifted at rates of between ca. 0.38 and $0.71 \mathrm{~mm} / \mathrm{yr}$ (Babić et al., 1978; Hećimović, 1987). Ongoing fault activity in the study area is also corroborated with historical and instru- 


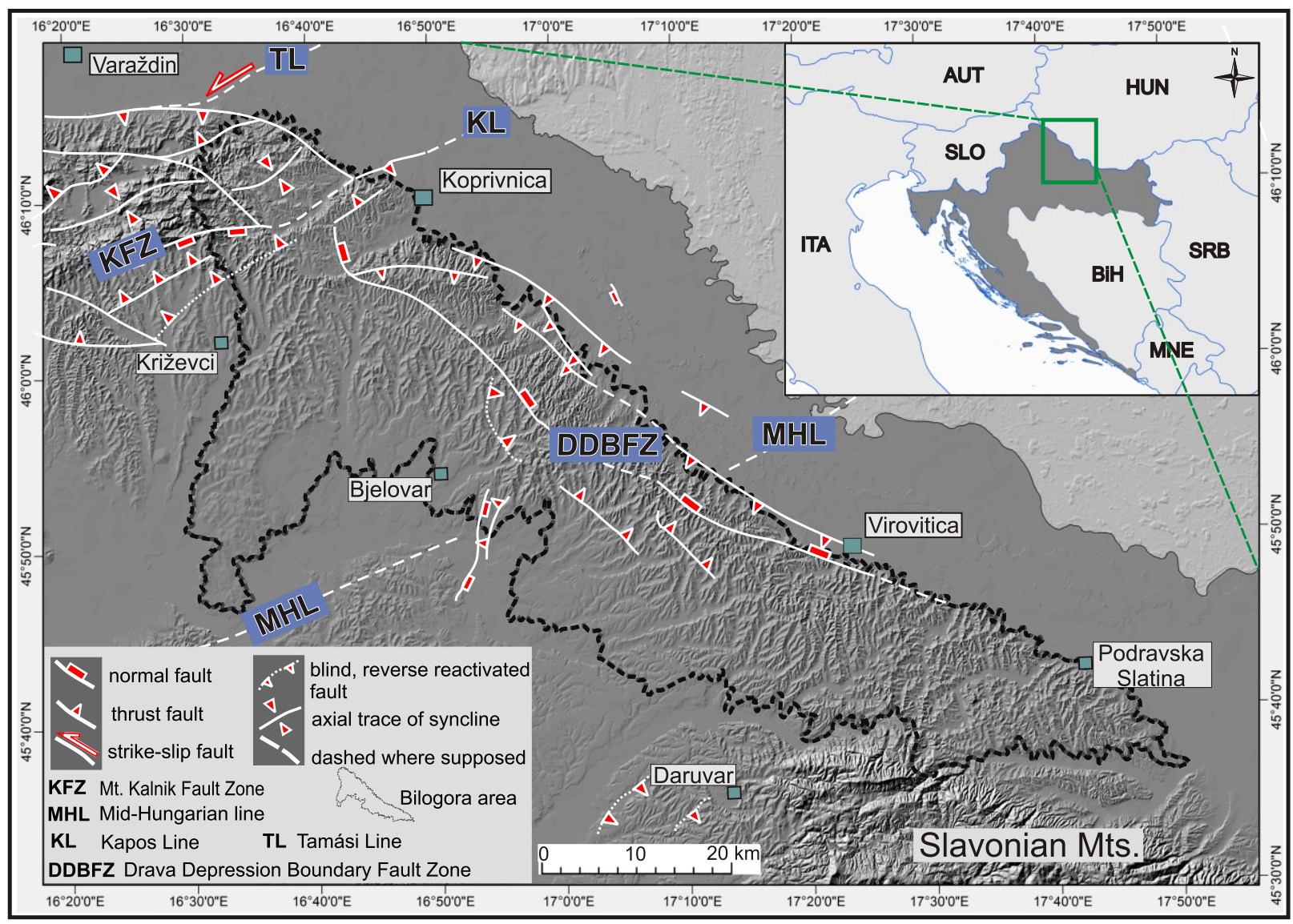

Fig. 1. Late Pontian to recent active faults and folds in NE Croatia

(after Prelogović et al., 1998; Tomljenović and Csontos, 2001; Matoš, 2014)

The geographic position of the study area is indicated by the green polygon

mentally-recorded seismicity. Epicenter locations indicate preferable clustering of earthquakes within the NE-SW and NW-SE striking Kalnik-Koprivnica and Drava-Bilogora epicentral zones, which correlate with the Mt. Kalnik Fault Zone (KFZ) and DDBFZ (Figs. 1 and 2) respectively (Herak et al., 2009; Matoš et al., 2016).

Here, we present additional evidence for Quaternary fault activity and near-surface deformation along the NE slope of Bilogora, documented by GPR profiling. After an overview of the geological and seismological setting of Bilogora, the GPR data acquisition and processing procedures are presented. This is followed by description of the $2 \mathrm{D}$ radar sections and their interpretation in relation to possible near-surface fault structures. Finally, we discuss our results in the context of the previous geomorphological and structural investigations in the study area, with the primary objective of inferring possible evidence of recent fault activity and near-surface fault segmentation in the area.

\section{TECTONIC SETTING}

\section{GEOLOGICAL SETTING OF THE STUDY AREA}

The area of Bilogora defines a Plio-Quaternary morphostructural unit located along the SW margin of the Drava Depression that is ca. $90 \mathrm{~km}$ long and $10 \mathrm{~km}$ wide with a relative relief lower than $200 \mathrm{~m}$. The landscape morphology of Bilogora is characterized by rolling hill topography (Fig. 3), with prominent NE and SW asymmetrical slopes that are generally dissected by deep and short gullies, dominantly drained by occasional colluvium-dominated flows.

The tectonic evolution of Bilogora, representing a NE fragment of the Croatian part of the Pannonian Basin System (CPBS), is linked with the youngest tectonic stage in evolution of the Pannonian Basin System (PBS) (e.g., Prelogović et al., 1998; Lučić et al., 2001; Malvić et al., 2003; Saftić et al., 2003; Malvić and Velić, 2011; Matoš et al., 2016). The tectonic evolution of the PBS started with the Late Oligocene to Early Miocene collision between the Adria Microplate and the European Plate that yielded an E-directed extrusion of the ALCAPA crustal block, and an E-W directed extension of the PBS embayment with formation of NNW-SSW striking rift- and wrench-related troughs (Royden and Horváth, 1988; Nagymarosy and Müller, 1988; Ratschbacher, 1991; Ratschbacher et al., 1991; Fodor et al., 1998; Tari and Pamić, 1998; Tari et al., 1999; Horváth and Tari, 1999; Steininger and Wessely, 1999; Lenkey et al., 2002; Csontos and Vörös, 2004; Ustaszewski et al., 2008). During the Middle and Late Miocene in the PBS, the dominant extension co-existed with post-rifting thermal subsidence and interchanged with compression episodes that, in the Pliocene and Quaternary, evolved to the reactivation and inversion of older structures in contractional and transpressional deformation conditions (Royden and Horváth, 1988; Bada et al., 1999; Horváth and Tari, 1999; Rögl, 1999; Tomljenović and 


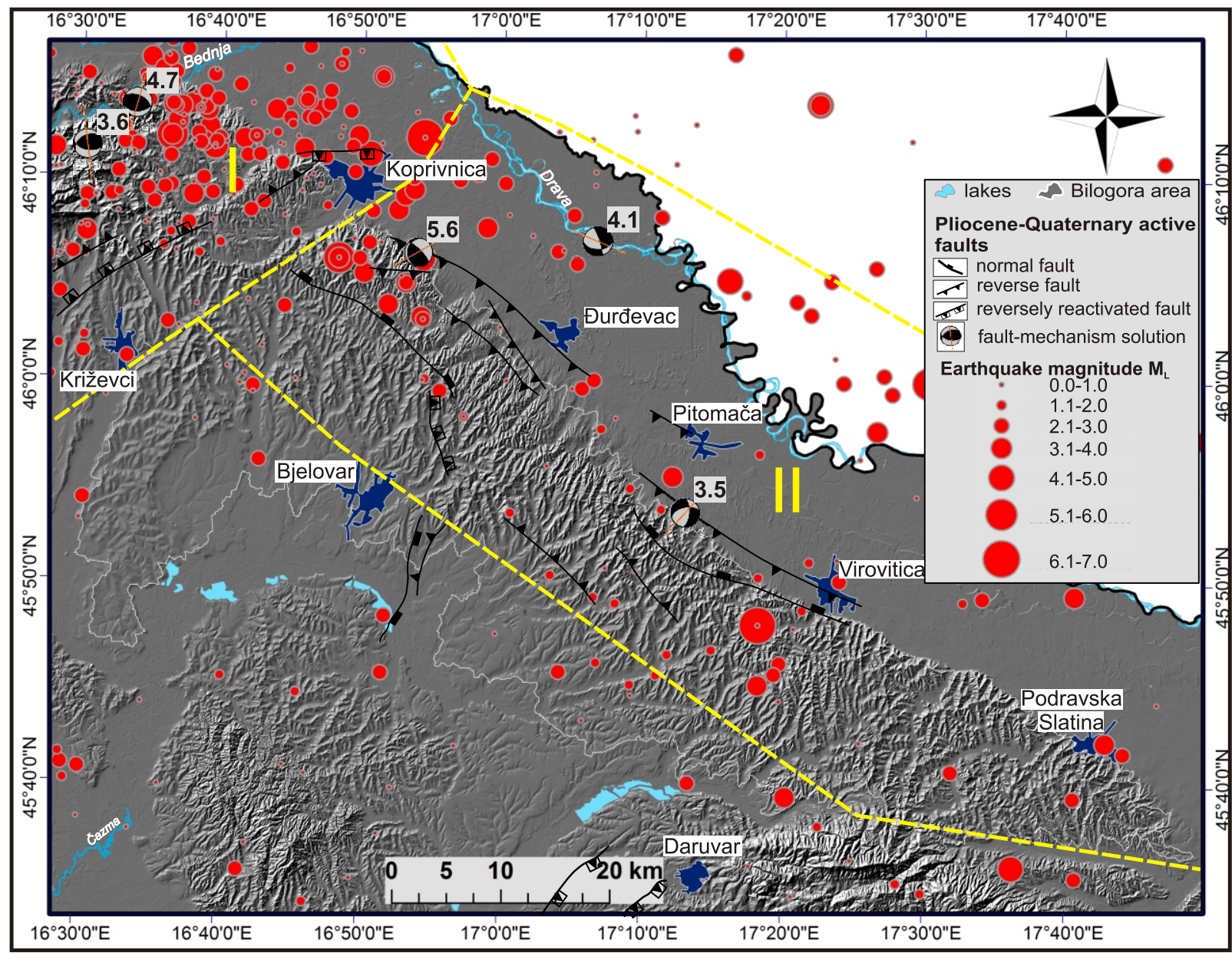

Fig. 2. Seismotectonic map of Bilogora showing the distribution of recorded historical seismic events (in years 567-2012; after Croatian Earthquake Catalogue), focal-mechanism solutions (FMS; after Herak et al., 2009) and traces of Plio-Quaternary active faults (after Matoš, 2014)

I - Kalnik-Koprivnica epicentral area, II - Drava-Bilogora epicentral area (after Herak et al., 2009)

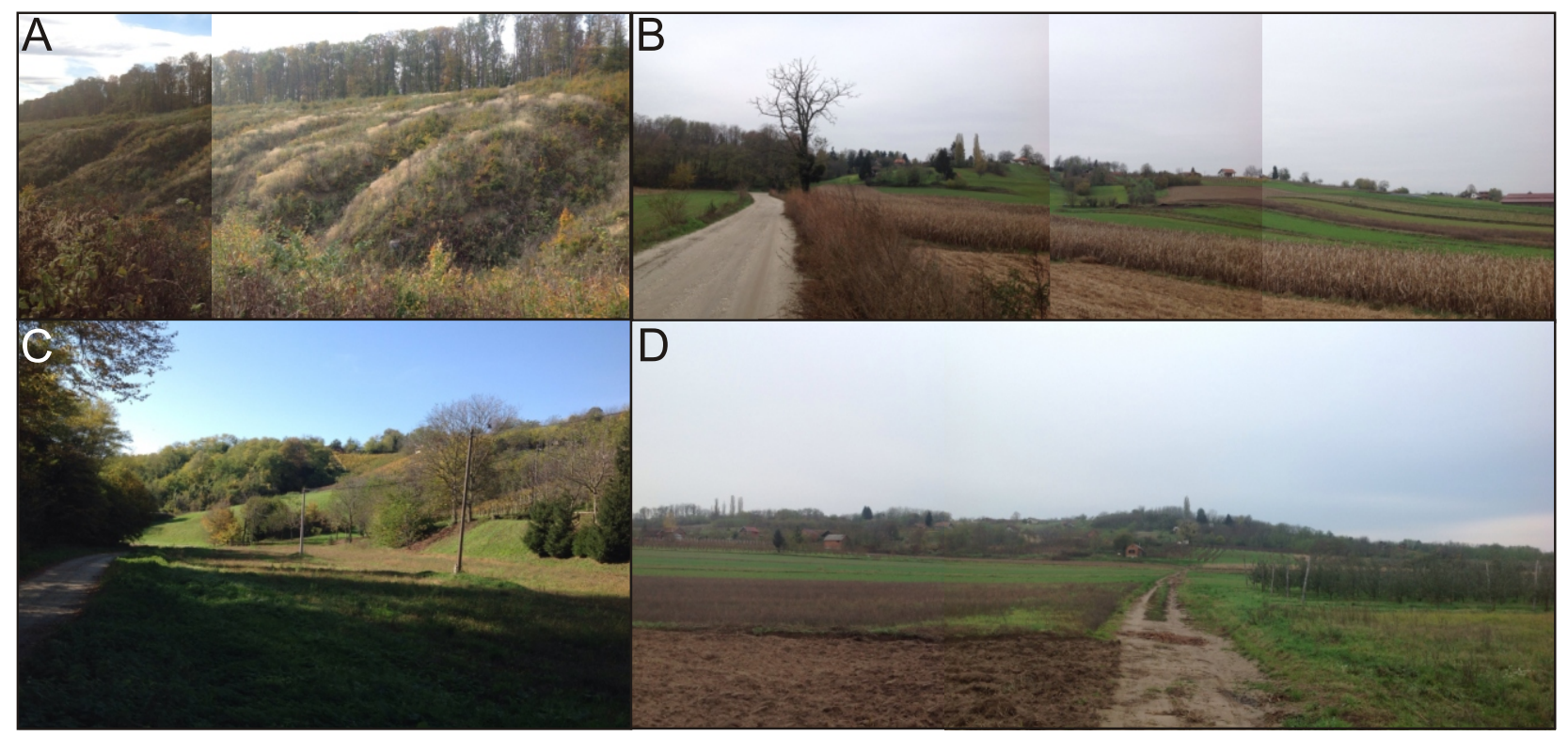

Fig. 3. Typical landscapes in the area of Plio-Quaternary active faults in Bilogora: "rolling hill" topography with deep, short and steep slope gullies, sporadically drained by colluvium-dominated flows

A, B - landscape in NW Bilogora; C - landscape in the central part of Bilogora; D - landscape in the SE part of Bilogora 
Csontos, 2001; Saftić et al., 2003; Fodor et al., 2005; Bada et al., 2007; Jarosiński et al., 2011; Malvić and Velić, 2011). In the Pliocene and Quaternary, Bilogora experienced a transpressional regime under the influence of the adjacent NW-SE striking DDBFZ (Babić et al., 1978; Hećimović, 1987; Prelogović et al., 1998 and references therein; see Fig. 1). The DDBFZ, a SW marginal fault of the Drava Depression, was transformed from an originally normal listric fault into a dextral fault that accommodated tectonic uplift and relatively high deformation of Pliocene and Quaternary deposits (Prelogović et al., 1998 and references therein; Velić et al., 2002; Saftic et al., 2003; see Fig. 4). The Pliocene sedimentary succession was characterized by the deposition of sand- and clay-rich marls in the remnants of the freshwater of Lake Pannon, which, due to the increased sediment influx, steadily progressed into Quaternary marshy and alluvial environments (Galović et al., 1981; Korolija et al., 1986; Marković, 1986; Hećimović, 1987; Šimunić et al., 1994; Lučić et al., 2001; Velić et al., 2002; Saftić et al., 2003 and references therein). Conditioned by the sediment source area and distinctive climate oscillations (i.e. glacial and interglacial stages) in the Quaternary, sedimentation in the Bilogora area was genetically linked to the Drava River drainage system and cyclic deposition of the weakly- to poorly-consolidated gravel strata alternating with sands, silts, soft clays, and occasionally lignite beds (Babić et al., 1978; Galović et al., 1981; Korolija et al., 1986; Marković, 1986; Hećimović, 1987; Šimunić et al., 1994; Lučić et al., 2001; Velić et al., 2002; Saftić et al., 2003; Matoš et al., 2016). In the Quaternary, aggradational deposition of the Drava River drainage system determined the formation of four river terraces. The oldest, Lower to Middle Pleistocene terrace was characterized by the deposition of a ca. $80 \mathrm{~m}$ pile of quartz-rich "Belvedere gravels" (Babić et al., 1978 and references therein), whereas a younger, Middle Pleistocene river terrace added an additional ca. $100 \mathrm{~m}$ of sediments (see Babić et al., 1978 and references therein). These terraces, with gravels dominantly rich in metamorphic, eruptive and quartzite clasts (Alpine source area), sand beds, and subordinate thin layers of silt and clays, were consequently covered by periglacial loess and loess-like strata ( $\leq 50 \mathrm{~m}$ in thickness) deposited in the Late Pleistocene, i.e. Würm Glacial period (ca. 120,000-10,000 ka; Fig. 4; see Babić et al., 1978; Galović et al., 1981; Korolija et al., 1986; Marković, 1986; Hećimović, 1987; Šimunić et al., 1994).

The final tectonic uplift of Bilogora in late Middle Pleistocene to Holocene time (Babić et al., 1978; Hećimović, 1987) yielded Drava River watercourse migration towards the NE. This conditioned the Drava River incision and the formation of two erosional-accumulative Drava River terraces separated by distinctive risers and covered by a spacious floodplain. Besides the deposition of terrace sequences (ca. $25 \mathrm{~m}$ of deposits) and fine-grained floodplain sediments, the Holocene sedimentary succession in the study area was characterized by the deposition of aeolian deposits, i.e., fine-grained sands, silts and loess with thicknesses $\leq 20 \mathrm{~m}$ (Hećimović, 1987). At the same time, Bilogora was also characterized by colluvial- and fluvial-dominated erosion and stream incision processes, which yielded slope mass wasting and the formation of a dissected hilly landscape ( $\leq 300 \mathrm{~m}$ a.s.l.) with deep and short gullies (Fig. 3$)$. The youngest, most recent sedimentary cover of Bilogora ca. $2 \mathrm{~m}$ in thickness is dominantly represented by slope-wash redeposited and weathered aeolian deposits (i.e., fine-grained sand, silt and loess, loess-like sediments) that are sporadically covered by i) recent stream sandy gravel deposits, and ii) fine-grained sands, sandy silts and clay-rich silts deposited by flood events
(Babić et al., 1978; Galović et al., 1981; Korolija et al., 1986; Marković, 1986; Hećimović, 1987; Šimunić et al., 1994).

\section{HISTORICAL AND INSTRUMENTAL RECORDS OF SEISMICITY IN BILOGORA}

The historical and instrumental seismicity in the Bilogora region indicates moderate earthquake occurrences, with only a few strong earthquakes $(M \geq 5.6)$ (Herak et al., 2009 and references therein). Concentrated in the NW, SE, and the central portion of Bilogora (Fig. 2), earthquakes are clustered within the areas of the NW-SE striking Drava Depression Boundary Fault Zone and NE-SW striking Mt. Kalnik Fault Zone (Fig. 1) with most foci concentrated at depths between 5 and $17 \mathrm{~km}$ (Herak et al., 2009). Though the relationship between the locations of the recent active faults and ongoing seismicity is poorly constrained, focal-mechanism solutions (FMS) in the Bilogora area obtained from the earthquakes with magnitudes over 3.5 indicate the prevalence of compressional and transpressional stress regimes (Herak et al., 2009). In the NW part of the study area (Fig. 2), subhorizontal to moderately dipping P-axes that strike N-S and NE-SW indicate the prevalence of a compressional stress field (Herak et al., 2009 and references therein). Available FMS in the north-westernmost part of the study area, i.e. Kalnik-Koprivnica epicentral area (Fig. 2) additionally suggests two possible E-W to ESE-WNW striking reverse fault planes as possible seismogenic sources in the area (Herak et al., 2009). In contrast to the NW part of the study area, in the SE part, i.e. the Drava-Bilogora epicentral area (Fig. 2), three available FMSs with NW-SE and NE-SW directed Paxes indicate stress field changes with prevalence of transpressional and transtensional stress regimes with dominant strike-slip motions (Herak et al., 2009). FMS point to either NE or NW dipping reverse seismogenic fault planes (see FMS of magnitude 5.6 event; Fig. 2) in the central part, whereas in the SE part of study area (see FMS of magnitude 3.5 event; Fig. 2), FMS suggests possible N-S, NE-SW striking dextral or sinistral seismogenic fault planes (Herak et al., 2009).

Historical seismicity records, extending back to the 6th century, indicate several devastating earthquakes related to the Drava Depression Boundary Fault Zone in the years 1694, 1757, 1778, 1836 and 1883, and to Mt. Kalnik. With macroseismic intensity up to $\mathrm{VIII}{ }^{\circ} \mathrm{MCS}$, these seismic events were associated with significant masonry damage, occurrences of ground cracks, liquefaction features, and overflowed water wells within the study area (Herak et al., 2009 and references therein).

\section{METHODOLOGY OF GROUND PENETRATING RADAR PROFILING}

The GPR profiles in this study were collected in 2013 at six locations along the Subotica Podravska-Koprivnički Ivanec (P1), the Glogovac-Kalinovac (P2), the Virje-Čepelovac (P3), the Javorovac-Čepelovac (P4), the Čurlovac-Veliko Trojstvo (P5), and the Mala Črešnjevica-Taborište (P6) faults (Fig. 5). The locations investigated of possible recent shallow subsurface deformation in the study area that could be related to the mapped Pliocene and Quaternary active faults (Figs. 5 and $6 \mathrm{~B})$ were selected according to the results of the DEM-based landscape morphometric analysis performed in ESRI ArcGIS, 


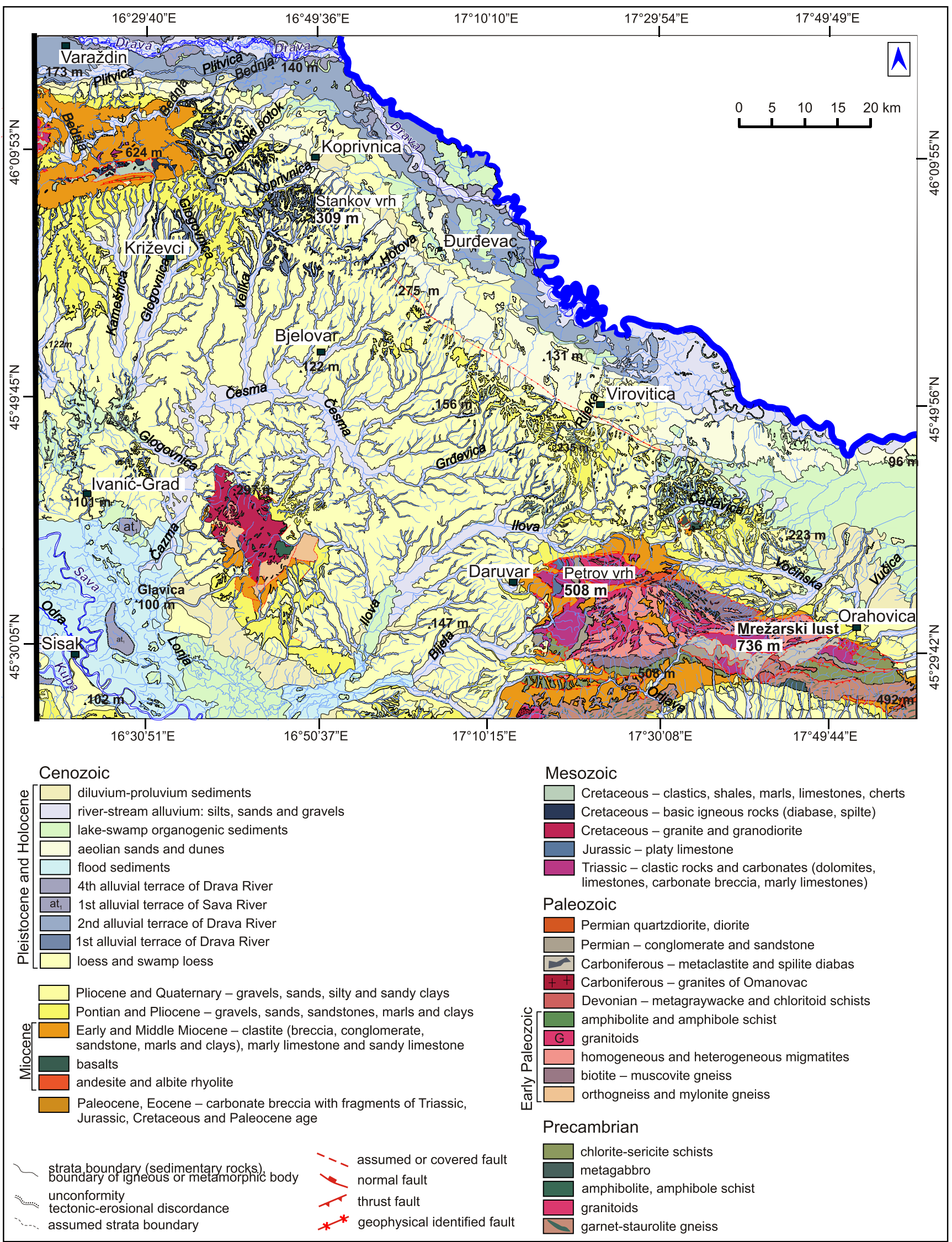

Fig. 4. Geological map of the Bilogora area (after Matoš, 2014, simplified after Šimunić et al., 1994; based on Galović and Marković, 1979; Korolija and Crnko, 1985; Marković, 1985; Hećimović, 1986; Jamičić and Brkić, 1987; Pikija, 1987; Jamičić, 1989; Crnko, unpublished) 
and structural analysis and fault modelling of 2D seismic reflection profiles and exploration wells performed using Petrel Seismic to Simulation Software ( ${ }^{\mathrm{TM}}$ Schlumberger) (Fig. 6B; Matoš, 2014; Matoš et al., 2016).

The locations of the GPR profiles surveyed were selected with the aid of a synoptic map of the spatial distribution of the Relative Tectonic Activity (RTA) index, which was overlaid with the projected surface traces of the identified Pliocene and Quaternary active faults (Fig. 5; see Matoš, 2014 for details). The RTA index map used, that suggested higher ongoing tectonic activity along the NE mountain front (Fig. 5), was constructed by ArcGIS-based methodology, which summarized several morphometric parameters (relief and slope-angle variability distributions, hypsometric integral, longitudinal profile concavity factor, maximum concavity and basin asymmetry factor; see Fig. 6A) by raster overlay and weighted sum procedure. At the same time, intersections of the identified Pliocene and Quaternary active faults were retrieved by the delineation of the intersection areas between the modelled fault planes and structure surface of the base Pliocene-Quaternary unconformity (Matoš,
2014 and references therein). Accordingly, by combining map overviews of the areas with the highest RTA index values and surface traces of Pliocene and Quaternary active faults (Fig. 5), we were able to point out several possible GPR testing locations in the study area. These locations, beside positive correlation between the RTA index map and mapped fault location were additionally investigated within several geomorphic field campaigns. Field observations show the best correlation between the landforms, RTA index map, and mapped fault locations in the central part of the NE mountain front, whereas in the NW and SE parts of the study area, a correlation was observed between the mapped fault traces and landforms (see Fig. 5). Considering the limitations of the strongly dissected topography, dense forest vegetation, and anthropogenic influence in the study area, five GPR profiles (P1-P3 and P5, P6) were surveyed perpendicular to fault surface traces, whereas one surveyed GPR profile, i.e. P4, was recorded oblique to a fault trace (Fig. 7). The surveyed GPR profile lengths varied between 157 and $701 \mathrm{~m}$. The location names, starting and ending points, and profile azimuths are given in Table 1.

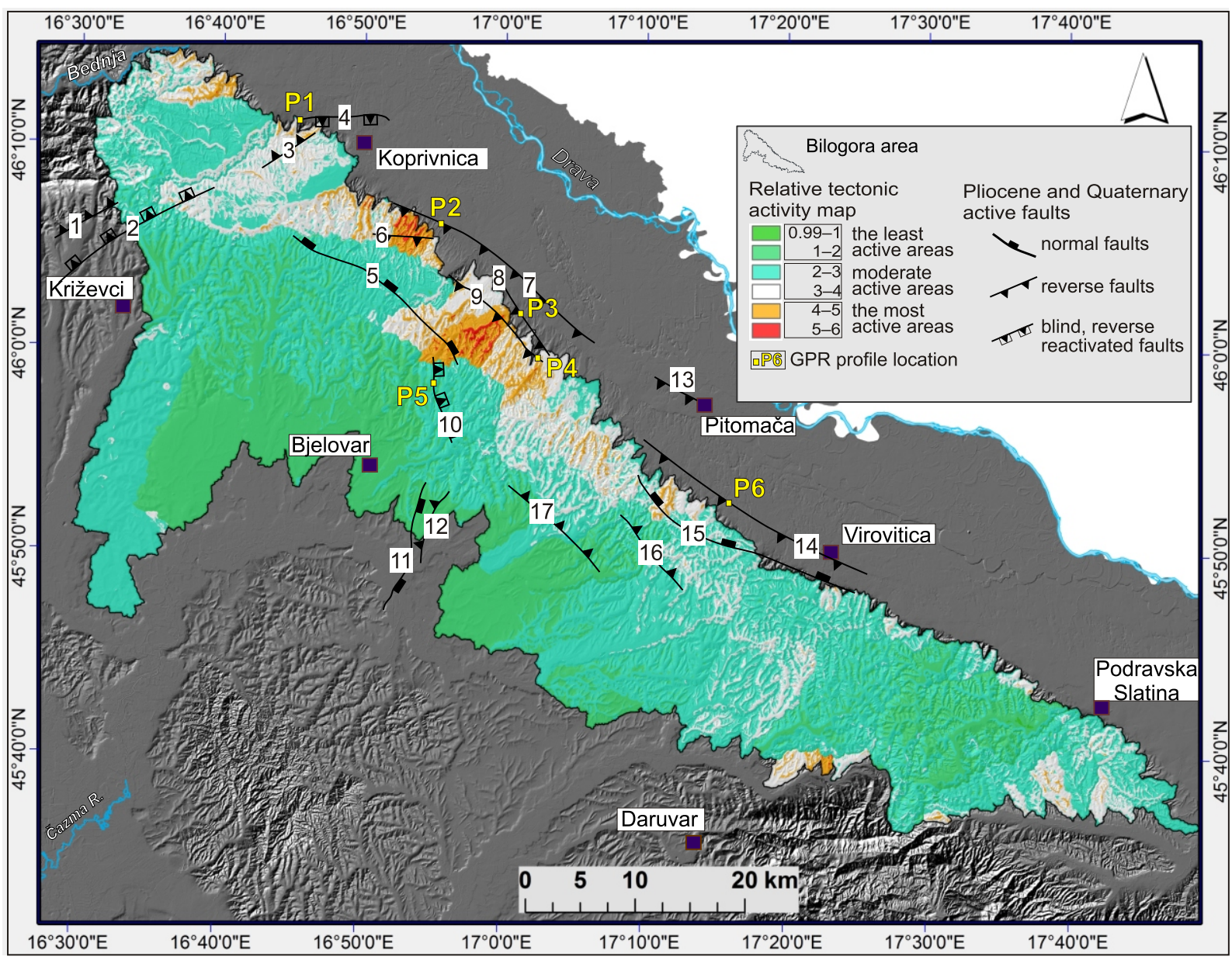

Fig. 5. Synoptic map of relative tectonic activity index (RTA) overlaid by traces of mapped Plio-Quaternary active faults in NE Croatia (after Matoš, 2014; Matoš et al., 2016)

The locations of six surveyed GPR profiles are indicated with yellow squares. Plio-Quaternary active faults: 1 - Selanec-Poganac, 2 - Salamunovec-Veliki Botinovac, 3 - Jankovec-Kunovec Breg, 4 - Subotica Podravska-Koprivnički Ivanec, 5 - NW Drava, 6 - Glogovac-Plavšinac, 7 - Glogovac-Kalinovac, 8 - Virje-Čepelovac, 9 - Javorovac-Čepelovac, 10 - Čurlovac-Veliko Trojstvo F., 11 - D. Gaj-Tomaš, 12 - Nevinac-Velika Ciglena, 13 - Kladare-Pitomača, 14 - Mala Črešnjevica-Taborište, 15 - SE Drava, 16 - Bačkovica-Cremušina, 17 - Kašljevac-Polum; for other explanations see text 


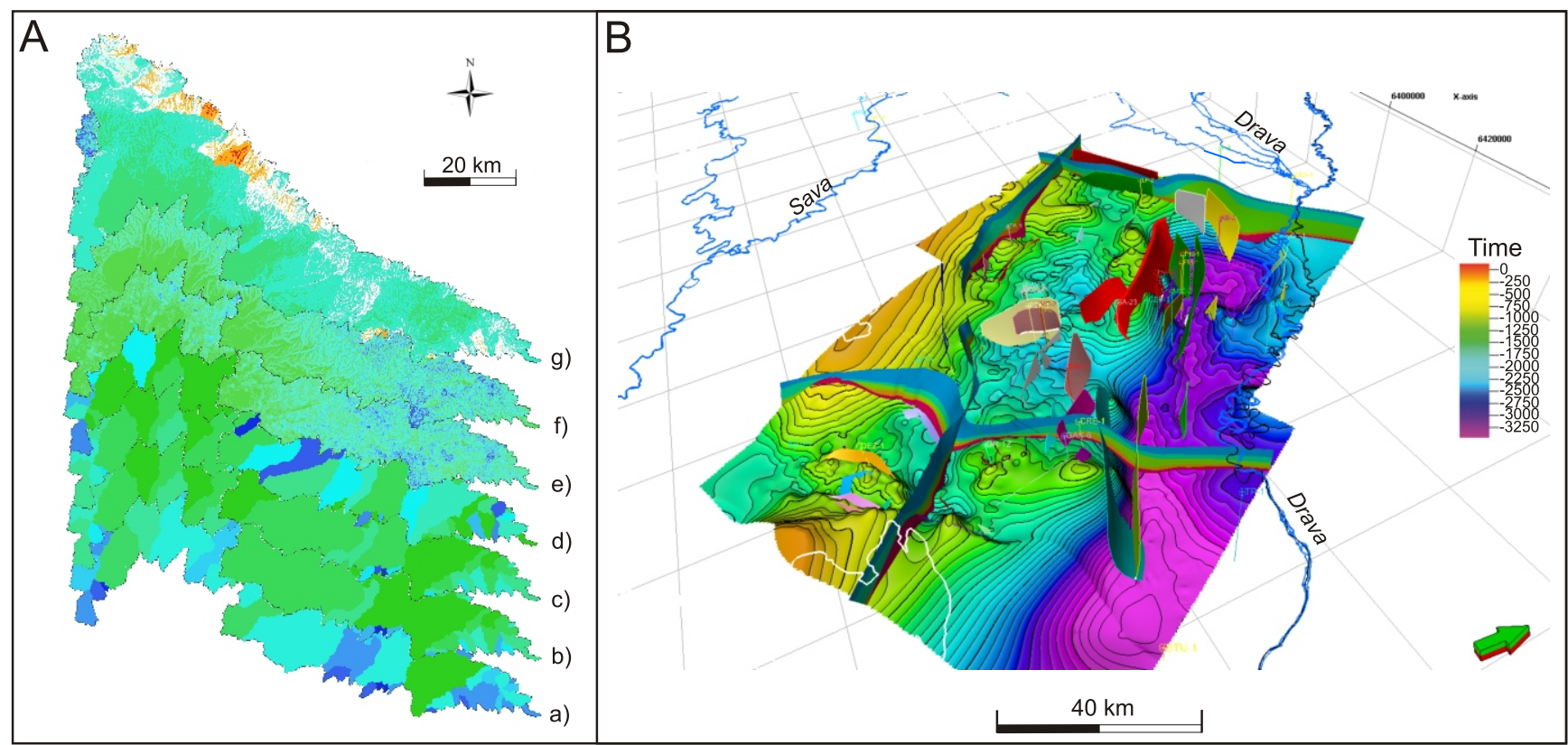

Fig. 6A - construction of relative tectonic activity (RTA) index map, using ArcMap (TMESRI) software-conveyed methodology. The procedure consists in extracting and stacking several morphometric parameters with elevation values derived from the digital elevation model (DEM). The parameters of: a - hypsometric integral, b- maximum concavity, $c$ - concavity factor, $d$-asymmetry factor, e - slope angle variability, $\mathrm{f}$ - local relief, were extracted using DEM of $10 \mathrm{~m}$ resolution, normalized and converted to rasters. The obtained rasters were subsequently stacked, using GIS raster weighted sum procedure, which resulted in the synoptic RTA index map (g); B - resultant structural model with interpreted neotectonic active faults in Bilogora prepared with the aid of Petrel Seismic to Simulation Software ( ${ }^{\mathrm{TM}}$ Schlumberger). Structural interpretations of stratigraphic horizons and fault planes were based on 72 2D seismic reflection profiles and 33 exploration boreholes. Surface traces of the Pliocene and Quaternary fault planes were retrieved by intersection of the fault planes and structural surface of the Base Pliocene-Quaternary unconformity (see Matoš, 2014; Matoš et al., 2016 for details)

\section{GPR INTERPRETATION METHODOLOGY}

The GPR profiles are commonly used to provide information for stratigraphic and sedimentological studies, however, the same data often corroborate near-surface deformation structures, i.e. resulting from recent, Quaternary fault activity (Ferry et al., 2004; Neal, 2004; Patidar et al., 2007). The interpretation of possible deformation along the observed GPR profiles often makes use of principles of seismic stratigraphy, the techniques developed within the petroleum industry to improve the interpretation of seismic reflection sections (Neal, 2004 and references therein).

In this study, the interpretation procedure of possible Quaternary fault activity along the GPR profiles measured was similar to the procedures proposed by Meschede et al. (1997), Rashed et al. (2003), Ferry et al. (2004), and Patidar et al. (2007). It comprised:

i) the recognition of the radar facies that delineate different lithological domains;

ii) the identification of the reflection truncations that allocate fault planes.

The latter was identified by diffuse signal character - which were associated with the fault-produced structures - lateral termination of reflection groups, and by changes in reflection patterns and amplitudes.

\section{GPR MEASUREMENTS AND GPS POSITIONING}

The GPR dataset (Fig. 7) was collected using the Malå ProEx GPR acquisition system unit, coupled with an unshielded
$50 \mathrm{MHz}$ Rough Terrain Antenna (RTA) (Fig. 8). We combined the backpack-mounted Malå ProEx control unit with a flexible tube-shaped RTA antenna that has been specially designed for rugged terrains and successfully used in rough conditions (e.g., Zajc et al., 2014, 2015). The total length of the used $50 \mathrm{MHz}$ RTA was $9.25 \mathrm{~m}$, with $4 \mathrm{~m}$ distance between the transmitting and receiving antennas.

In this study, a $50 \mathrm{MHz}$ antenna was used as the best compromise between the desired depth penetration (up to $25 \mathrm{~m}$ ) necessary for geological applications and the quality resolution of a radar section that is required for the detection of vertical displacements on relatively small faults characteristic of weakly deforming regions (Jamšek et al., 2011a; Jamšek Rupnik, 2013). The data acquisition was carried out with a distance-measuring mechanism, i.e. a profile encoder using a biodegradable cotton string and observing $0.2 \mathrm{~m}$ intervals between consecutive measurements (Malå, 2009).

Precise GPS positioning along the recorded GPR profiles was achieved with the Trimble R8 GNSS Positioning System (Fig. 8). The continuous GPS recording was operated on the basis of the CROPOS (CROatian POsitioning System) VRS (Virtual Reference Station) system. CROPOS is a State Geodetic Administration network of referent GNSS (Global Navigation Satellite System) CORS (Continuously Operating Reference Station) stations evenly distributed through the Croatian territory at distances of about $70 \mathrm{~km}$ apart (Marjanović, 2010; Marjanović and Link, 2011). The system allows for positioning in real time with DPS (Differential Positioning Service) and VPPS (High-Precision Positioning Service). In addition to real-time positioning, CROPOS allows for post-processing of data measurements (Post-Processing) in the form 


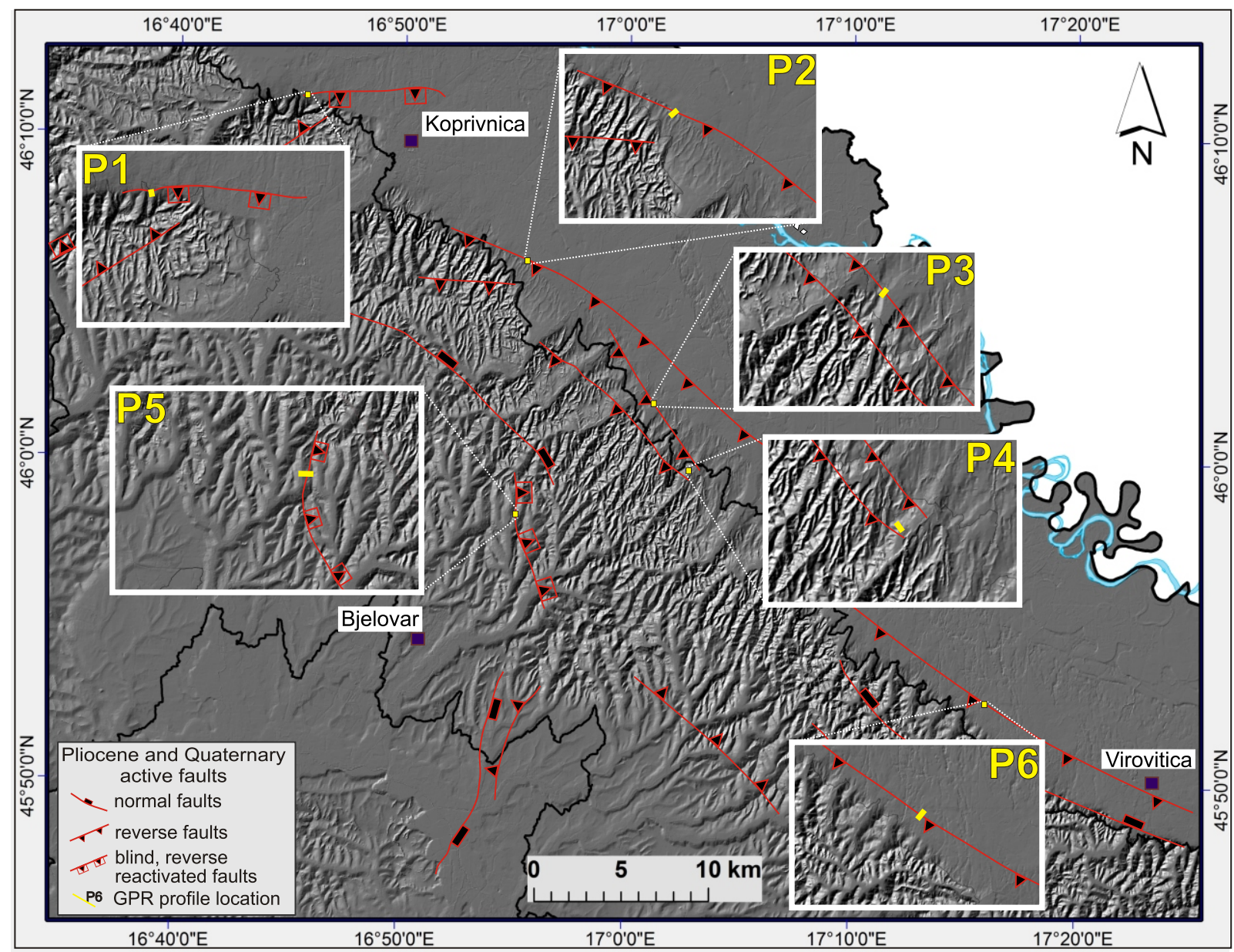

Fig. 7. GPR profile locations

P1 - Subotica Podravska-Koprivnički Ivanec Fault; P2 - Glogovac-Kalinovac Fault; P3 - Virje-Čepelovac Fault; P4 - Javorovac-Čepelovac Fault; P5 - Čurlovac-Veliko Trojstvo Fault; P6 - Mala Črešnjevica-Taborište Fault

GPR profiles - location, spatial orientation and total length

\begin{tabular}{|c|c|c|c|c|c|c|c|c|c|}
\hline \multirow{2}{*}{$\begin{array}{l}\text { GPR } \\
\text { profile }\end{array}$} & \multirow{2}{*}{ Location } & \multicolumn{3}{|c|}{ Start GPR point } & \multicolumn{3}{|c|}{ End GPR point } & \multirow{2}{*}{ Azimuth } & \multirow{2}{*}{$\begin{array}{c}\text { Length } \\
{[\mathrm{m}]}\end{array}$} \\
\hline & & $\varphi$ & $\lambda$ & $\mathrm{h}$ & $\varphi$ & $\lambda$ & $\mathrm{h}$ & & \\
\hline P1 & $\begin{array}{c}\text { Subotica } \\
\text { Podravska-Koprivnički } \\
\text { Ivanec }\end{array}$ & $46^{\circ} 11^{\prime} 9.4^{\prime \prime}$ & $16^{\circ} 44^{\prime} 58.4^{\prime \prime}$ & $176.8 \mathrm{~m}$ & $46^{\circ} 11^{\prime} 4.3^{\prime \prime}$ & $16^{\circ} 45^{\prime} 0.1^{\prime \prime}$ & $186.9 m$ & $170^{\circ}$ & 157.7 \\
\hline $\mathrm{P} 2$ & Glogovac-Kalinovac & $46^{\circ} 06^{\prime} 6.9^{\prime \prime}$ & $16^{\circ} 55^{\prime} 8.0^{\prime \prime}$ & $133.1 \mathrm{~m}$ & $46^{\circ} 05^{\prime} 58.8^{\prime \prime}$ & $16^{\circ} 54^{\prime} 54.4^{\prime \prime}$ & $141.9 m$ & $230^{\circ}$ & 384.9 \\
\hline P3 & Virje-Čepelovac & $46^{\circ} 01^{\prime} 39.3^{\prime \prime}$ & $17^{\circ} 00^{\prime} 34.4^{\prime \prime}$ & $148.2 \mathrm{~m}$ & $46^{\circ} 01^{\prime} 32.8^{\prime \prime}$ & $17^{\circ} 00^{\prime} 26.1^{\prime \prime}$ & $160.6 \mathrm{~m}$ & $230^{\circ}$ & 255.7 \\
\hline P4 & Javorovac-Čepelovac & $45^{\circ} 59^{\prime} 29.0^{\prime \prime}$ & $17^{\circ} 02^{\prime} 9.1^{\prime \prime}$ & $166.2 \mathrm{~m}$ & $45^{\circ} 59^{\prime} 37.3^{\prime \prime}$ & $17^{\circ} 02^{\prime} 0.5^{\prime \prime}$ & $194.0 \mathrm{~m}$ & $325^{\circ}$ & 317.8 \\
\hline P5 & Čurlovac-Veliko Trojstvo & $45^{\circ} 58^{\prime} 25.6^{\prime \prime}$ & $16^{\circ} 53^{\prime} 12.9^{\prime \prime}$ & $154.1 \mathrm{~m}$ & $45^{\circ} 58^{\prime} 26.0^{\prime \prime}$ & $16^{\circ} 53^{\prime} 45.7^{\prime \prime}$ & $188.8 \mathrm{~m}$ & $90^{\circ}$ & 701.0 \\
\hline P6 & Mala Črešnjevica-Taborište & $45^{\circ} 52^{\prime} 32.9^{\prime \prime}$ & $17^{\circ} 15^{\prime} 44.6^{\prime \prime}$ & $135.8 \mathrm{~m}$ & $45^{\circ} 52^{\prime} 20.3^{\prime \prime}$ & $17^{\circ} 15^{\prime} 29.7^{\prime \prime}$ & $142.2 \mathrm{~m}$ & $220^{\circ}$ & 492.0 \\
\hline
\end{tabular}

of a geodetic precise positioning service (GPPS) (Table 2). The VRS concept is based on a network of reference stations that are connected with a control centre that continuously collects data from all GNSS receivers in the network (Marjanović, 2010; Marjanović and Link, 2011). This informa- tion is used to create the VRS that is essentially a virtual point a few metres away from the GNSS rover. The rover receives and interprets the data in relation to a physical reference station located in the immediate vicinity (Marjanović, 2010; Marjanović and Link, 2011). 


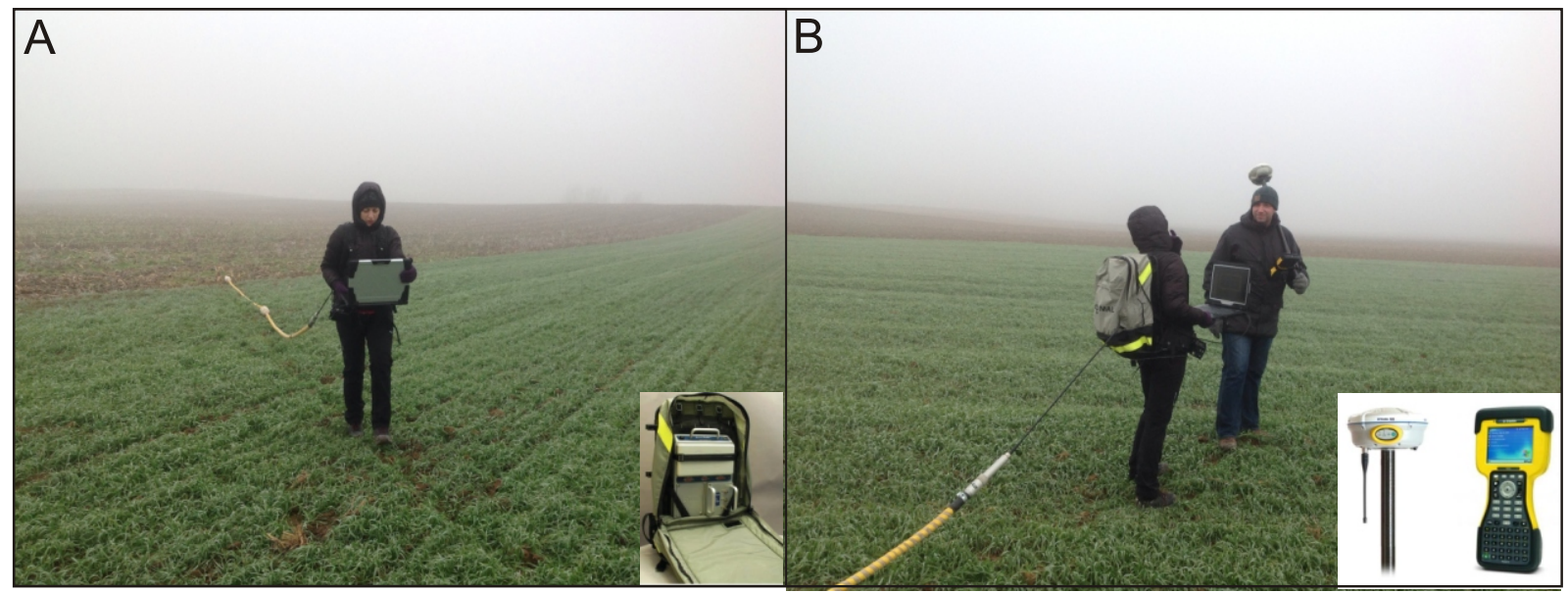

Fig. 8A - backpack-mounted acquisition system Malå ProEx GPR unit coupled with "snake-like" unshielded $50 \mathrm{MHz}$ rough terrain antenna used in this study; B - the continuous GPS positioning along the surveyed GPR sections was achieved with the Trimble R8 GNSS Surveying System, with vertical and horizontal accuracy in the range of a few centimetres (see Marjanović, 2010; Marjanović and Link, 2011 for details)

Croatian positioning system (CROPOS) geodetic services (after Marjanović and Link, 2011)

\begin{tabular}{|c|c|c|c|c|}
\hline $\begin{array}{c}\text { CROPOS } \\
\text { Service }\end{array}$ & Solution method & Accuracy & $\begin{array}{c}\text { Data } \\
\text { transfer }\end{array}$ & $\begin{array}{c}\text { Data } \\
\text { format }\end{array}$ \\
\hline DGP & $\begin{array}{c}\text { network solution of code measurements } \\
\text { in real time }\end{array}$ & $\begin{array}{c}\text { Wireless Internet (GPRS/UTMS), } \\
\text { NTRIP protocol }\end{array}$ & $0.3-0.5 \mathrm{~m}$ & RTCM \\
\hline VPPS & $\begin{array}{c}\text { network solution of phase measurements } \\
\text { in real time }\end{array}$ & $\begin{array}{c}\text { Wireless Internet (GPRS/UMTS), } \\
\text { NTRIP protocol, GSM }\end{array}$ & $\begin{array}{c}2 \mathrm{~cm}(2 \mathrm{D}) \\
4 \mathrm{~cm}(3 \mathrm{D})\end{array}$ & RTCM \\
\hline PPS & post-processing & Internet (FTP, e-mail) & $>1 \mathrm{~cm}(2 \mathrm{D}, 3 \mathrm{D})$ & RINEX \\
\hline
\end{tabular}

\section{DATA PROCESSING}

The GPR data collected alongside the recorded profiles were processed using the Reflexw 6.0.5. program, developed by Sandmeier software. The processing procedures (Fig. 9) included the definition of the initial geometry of the profiles, i.e. defining the GPR profile line start point, endpoint and midpoint coordinates. The GPR profile processing procedures included (Fig. 9):

1. Correction for Direct Current Amplitude Offset (DC Removal): interval set to $400-700 \mathrm{~ns}$;

2. Time Zero Adjustment (Correction for Maximum Phase and Start Time Move): time zero set to $49.5 \mathrm{~ns}$;

3. Background Removal: option "Whole line" selected;

4. Amplitude Corrections through Manual Gain: up to 400 ns;

5. Bandpass Frequency Filtering: the frequency range defined as follows: Low Cut $-25 \mathrm{MHz}$, Low Pass $50 \mathrm{MHz}$, High Pass $-75 \mathrm{MHz}$, and High Cut $-150 \mathrm{MHz}$;

6. 3D Topography Static Correction: based on elevations acquired from GPS measurements.

As shown in Figure 9A, raw radargrams contain a constant amplitude offset of the recorded traces, causing the radargram to appear grey. After removing this initial DC signal component, the data are moved back to the mean zero level, allowing the recorded traces to correctly display the positive and negative parts of the amplitude (Jol, 2009). Since the mean value of the set time interval has to correspond to the shift that we want to eliminate (Sandmeier, 2011), the time interval of 400 to $700 \mathrm{~ns}$ was used. This part of the raw radargram does not contain any reflections or anomalies that could affect the calculations of the mean shift value. The result of this process is shown in Figure 9B. Due to irregularities in the first arrival times that occur at the boundary between the air and the ground, all traces must be aligned with a common time zero before applying any further processing steps (Jol, 2009). In our case, all traces were positioned using the first negative peak at the time zero of $49.5 \mathrm{~ns}$ (Fig. 9C). Next, background removal was applied along the whole line (Fig. 9D). Due to GPR signal attenuation, the strength of the signal must be increased at greater depths, attained by applying gain processes (Neal, 2004). Figure $9 \mathrm{E}$ shows the result of manual gain in the y direction, where the data were gained up to $400 \mathrm{~ns}$, resulting in increased signal amplitudes along the traces. In order to eliminate the frequencies that are either too low or too high, bandpass frequency filtering was applied by defining four frequency values (low cut $25 \mathrm{MHz}$, low pass $-50 \mathrm{MHz}$, high pass $-75 \mathrm{MHz}$, and high cut $150 \mathrm{MHz}$ ). Thus, the values close to the peak signal frequency stay intact. As shown in Figure 9F, cutting off low and high frequencies improves the signal to noise ratio. The last processing step, shown in Figure 9G, is 3D topography static correction where the elevation values used were acquired from GPS measurements along Profile 1. 

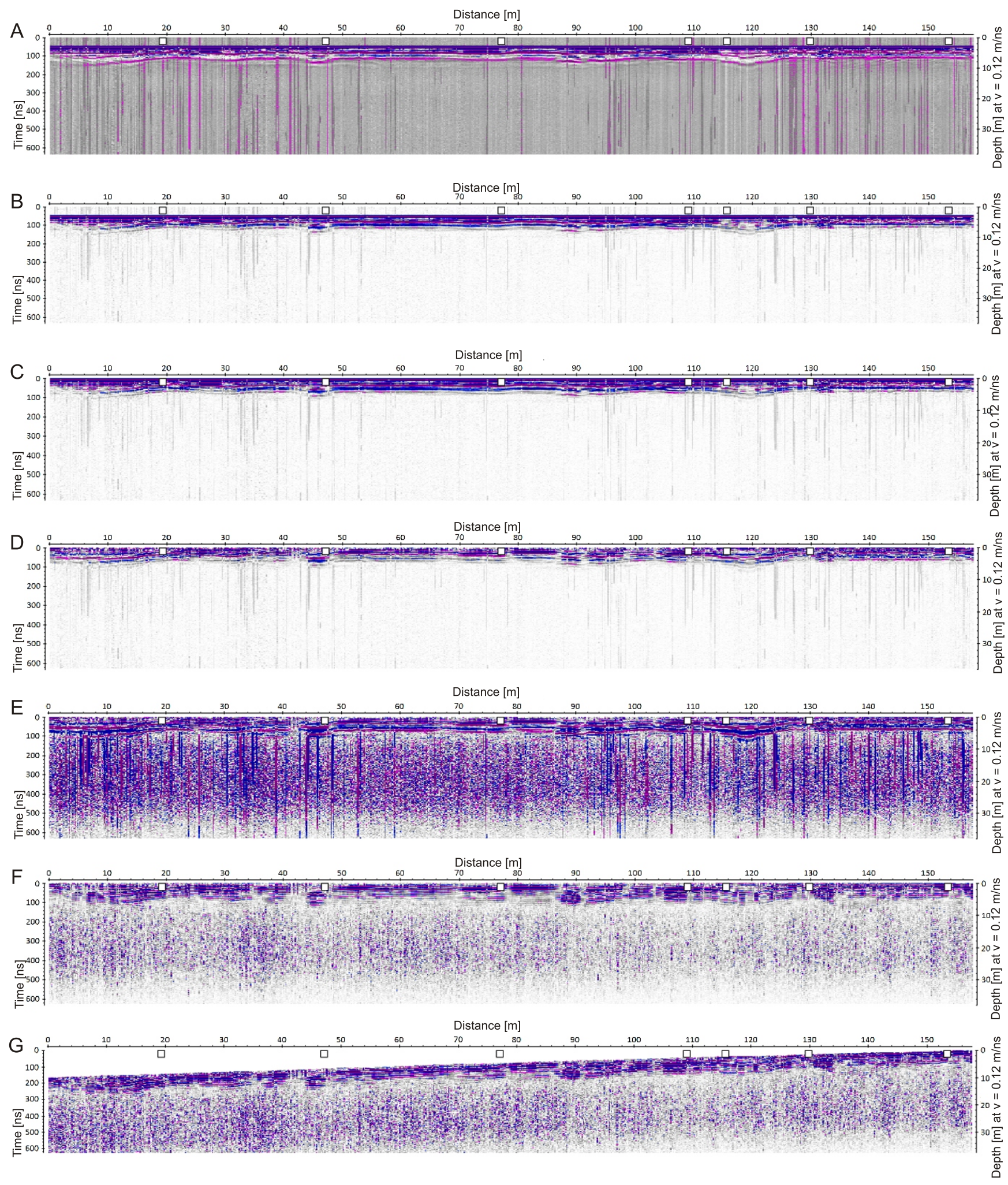

Fig. 9. Example of processing steps shown on GPR profile P1

A - raw radargram; $\mathbf{B}$ - after DC removal; C - after defining time zero and moving start time; $\mathbf{D}$ - after background removal; $\mathbf{E}$ - after manual gain; $\mathbf{F}$ - after bandpass frequency filtering; $\mathbf{G}$ - after 3D topography static correction 
Time to depth conversion of the GPR profiles was performed by determining the signal velocity of $0.12 \mathrm{~m} / \mathrm{ns}$ through hyperbola fitting. Hyperbola fitting can only be applied on profiles that contain diffraction hyperbolas caused by the presence of underground objects such as caves, boulders, pipes or electric cables. Fitting the ideal form of a hyperbolic function to an existing diffraction hyperbola gives us information on the velocity of the GPR signal, which is needed for the time to depth conversion (Jol, 2009). Diffraction hyperbolas can only be seen in the GPR profiles P1, P4, and P6 (Figs. 10, 13 and 16), however, they all give the same signal velocity information. As these three GPR profiles are located the farthest apart and still show similar subsurface conditions, the same signal velocity was also applied for the other three profiles that do not contain diffraction hyperbolas. It should be noted that this is only an estimate as local differences in hydrogeological settings on such an extensive research area can vary significantly and affect the velocity of signal propagation. As the objective of this study was not to accurately define the depth to tectonic structures, but rather to try and find evidence of recent fault activity, the accuracy of the time to depth conversion is not of key importance. The signal velocity used in this study is typical of sediments composed of alternating unsaturated sands and gravels interbedded with silts and clays (Grant and Schultz, 1996; Neal, 2004 and references therein) that correspond to the Pliocene and Quaternary sedimentary cover in Bilogora.

\section{RESULTS AND INTERPRETATION OF THE GPR PROFILES}

In this chapter we present the results of interpretations of the surveyed GPR profiles that indicate near-surface strata deformation, and evidence of Quaternary fault activity in the study area.

\section{GPR PROFILE P1}

The GPR profile P1 was recorded perpendicular to the E-W striking Subotica Podravska-Koprivnički Ivanec Fault in its westernmost part (Fig. 7). The area represents gentle topography with an elevation difference of ca. $9 \mathrm{~m}$ along the profile (Table 1). Near-surface sediments along the GPR profile are composed of Late Pleistocene loess and loess-like strata, covered by weathered and redeposited Holocene fine-grained sands and sandy silts with approx. thicknesses of between 2 and $4 \mathrm{~m}$ (Hećimović, 1995).

The $\mathrm{P} 1$ profile obtained is characterized by a moderate to high reflection strength within the first $300 \mathrm{~ns}$ that corresponds to ca. $12 \mathrm{~m}$ in depth (Fig. 10). The reflections are coherent, sub-parallel to the topography, and are only recognizable in the shallow portion of the profile. Though the fault scarp of the Subotica Podravska-Koprivnički Ivanec Fault was not recog-

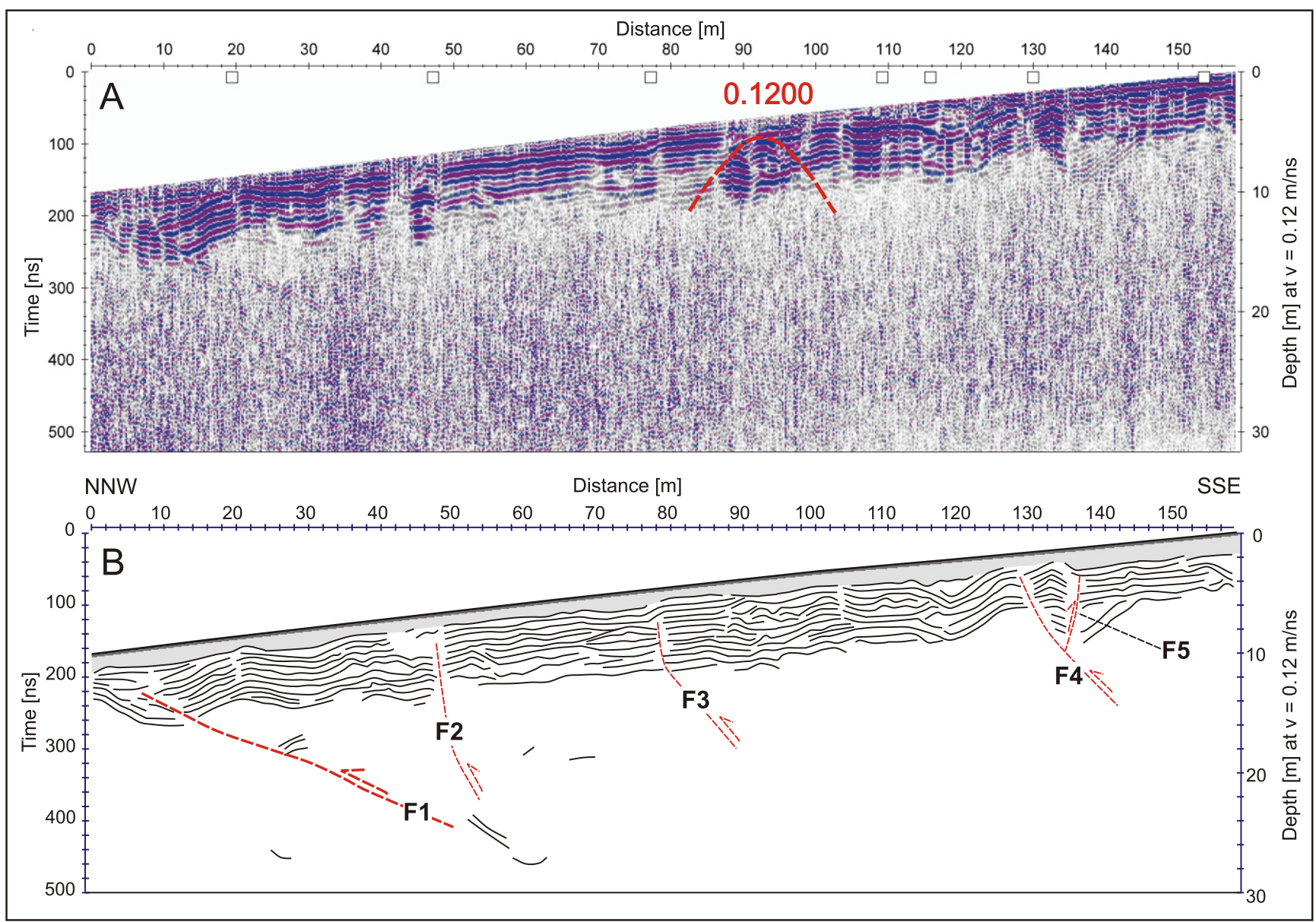

Fig. 10A - GPR profile P1 perpendicular to the Subotica Podravska-Koprivnički Ivanec Fault; hyperbola with signal velocity of $0.12 \mathrm{~m} / \mathrm{ns}$ is indicated by the red curve; B - interpreted GPR profile P1; grey hatching is related to the zone influenced by the direct wave; vertical exaggeration is ca. $2 x$ 
nized directly at the surface, the reflection facies and four reflector truncation areas along the $\mathrm{P} 1$ profile indicate near-surface fault activity (Fig. 10). These locations are characterized by the truncated reflector pattern, laterally lower amplitude strengths, corrugated reflection tapers, and geometrical differences between the reflection facies in the fault strands' hanging walls and footwalls (Fig. 10). Along the recorded GPR profile, identified fault strands are characterized by reverse motions, dominantly dipping towards the SSE (see F1-F4 in Fig. 10) and subordinately towards the NNW (see F5 in Fig. 10) at dip angles between 25 and $75^{\circ}$. The first fault strand (F1) is interpreted at a distance between 4 and $14 \mathrm{~m}$ as the main, shallow-dipping fault structure along the P1 profile (Fig. 10). The second fault strand (F2) is positioned between 40 and $50 \mathrm{~m}$, while the third fault strand (F3) is identified between 75 and 80 $\mathrm{m}$. The fourth and fifth fault strands (F4 and F5) that resemble a positive flower structure are recognized between 126 and $140 \mathrm{~m}$ (Fig. 10). The truncation of the shallowest reflectors at the interpreted fault strands show $\sim 0.5 \mathrm{~m}$ of vertical displacement. It can be considered that this represents the most recent displacement of the Quaternary deposits that could be associated with the Subotica Podravska-Koprivnički Ivanec Fault.

\section{GPR PROFILE P2}

The GPR profile presented in Figure 7 was recorded in the NW part of the NW-SE striking and NE dipping Glogovac-Kalinovac Fault that runs $\sim 10 \mathrm{~km}$ away from the town Koprivnica. The NE-SW striking and $385 \mathrm{~m}$ long GPR profile was re- corded across a subtle, ca. $9 \mathrm{~m}$ relative relief topography (Table 1) that gently increases towards the SW (Fig. 11). Near-surface sediments along the GPR profile are composed of weathered Holocene fine-grained sands (ca. 2-4 m) that are covered by younger clay-rich silts (ca. $3 \mathrm{~m}$ ), which were deposited by Drava River flooding events (see Hećimović, 1995).

The recorded P2 GPR profile exhibits strong reflectors in the shallow subsurface zone (ca. $340 \mathrm{~ns}$ ) that reach $-14 \mathrm{~m}$ in depth. Similar to that of $\mathrm{P} 1$, the reflectors are sub-parallel to the topographic surface. In addition to these strong reflectors, we can also identify air reflections, and areas with high signal attenuation (Fig. 11). The identified reflector truncations along the P2 profile can be attributed to power line and road track noise, high water saturation of near-surface sediments, and to the several near-surface fault strands (F1-F5) that offset the shallowest Quaternary deposits (Fig. 11). The fault strands within the Glogovac-Kalinovac Fault zone generally dip towards the SW (F1-F3) and NE (F4 and F5) at a dip angle between 60 and $80^{\circ}$, while the reflection geometry indicates possible reverse and normal motions. Two possible fault strands, F3 and F5, indicate a conjugate feature that probably enabled local subsidence within the central part of the profile, in the area between 130 and $220 \mathrm{~m}$ (Fig. 11), while the fault strands F2 and F4 represent another conjugate fault pair that suggests local uplift along the profile (Fig. 11). In combination with the F1 fault strand, the F2 and F4 fault strands characterize a topographic scarp between 60 and $160 \mathrm{~m}$ of the surveyed profile that cause $\sim 9 \mathrm{~m}$ difference in elevation between the lower NE and the higher SW part, suggesting very recent tectonic uplift of the youngest Quaternary deposits (Fig. 11).

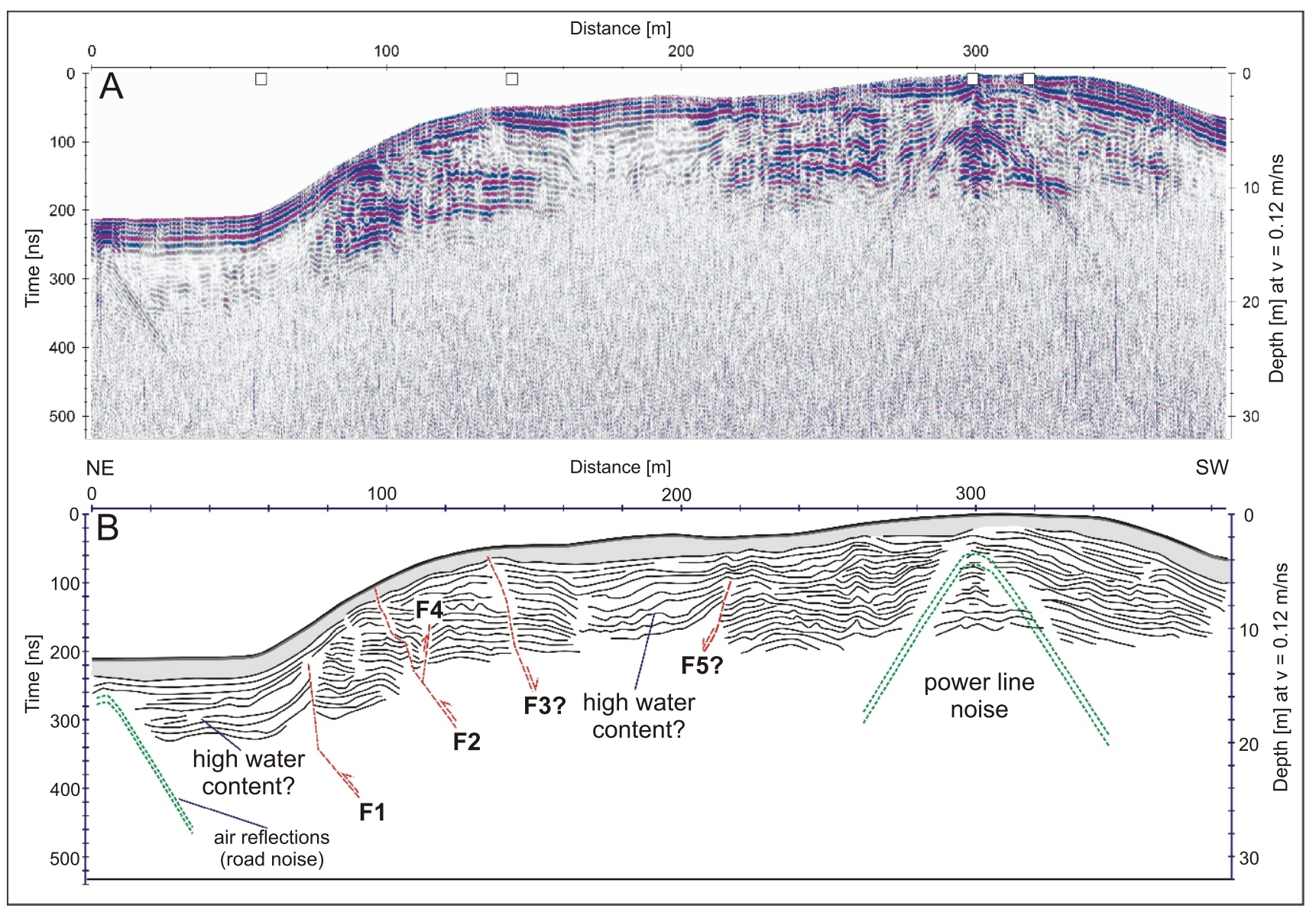

Fig. 11A - GPR profile P2 perpendicular to Glogovac-Kalinovac Fault; B - interpreted GPR profile P2; grey hatching is related to the zone influenced by the direct wave; vertical exaggeration is ca. $4 x$ 


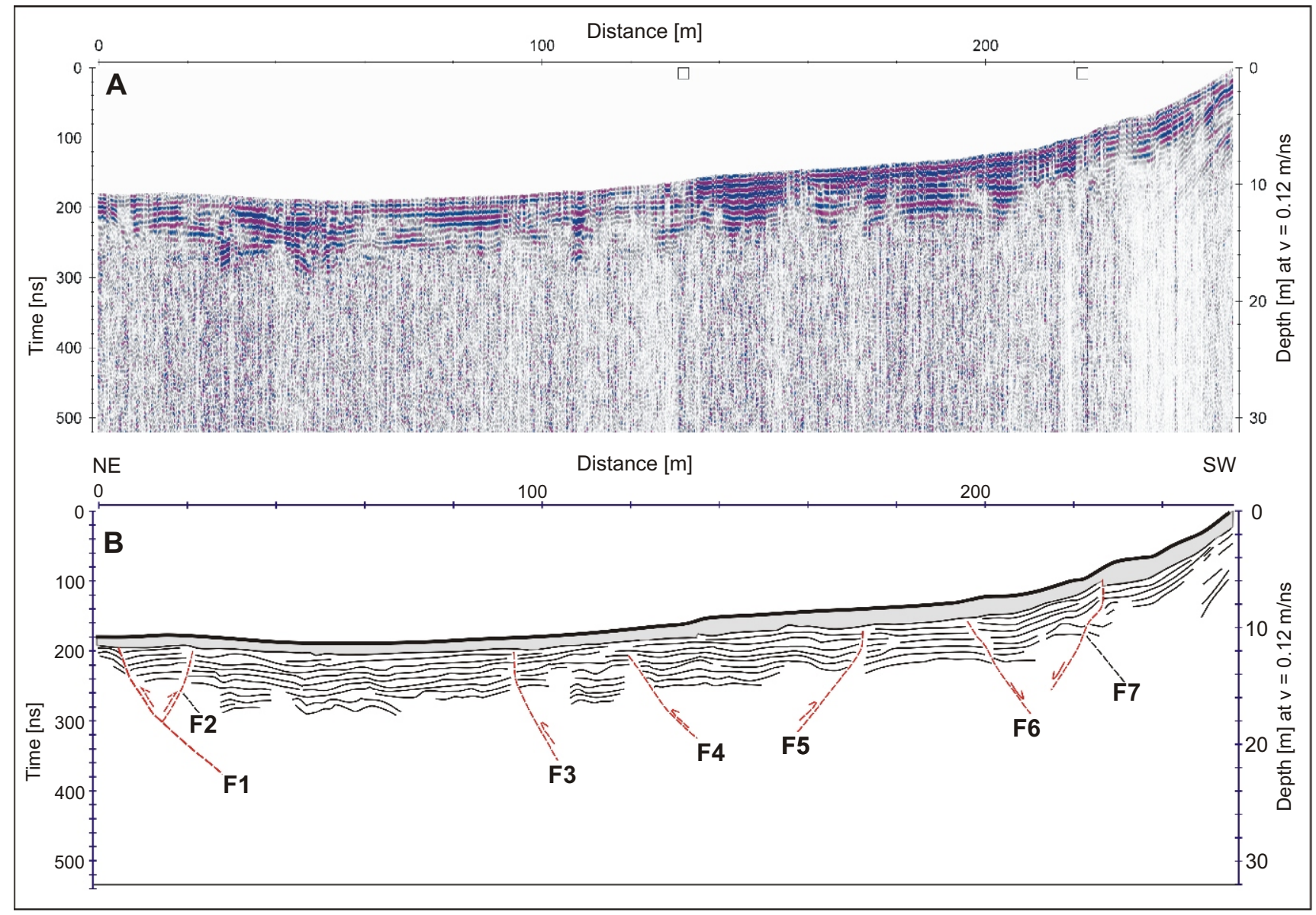

Fig. 12A - GPR profile P3 perpendicular to Virje-Čepelovac Fault; B - interpreted GPR profile P3; grey hatching is related to the zone influenced by the direct wave; vertical exaggeration is ca. $2.6 \mathrm{x}$

GPR PROFILE P3

This profile was recorded in the central part of Bilogora, in the central portion of the NW-SE striking Virje-Čepelovac Fault (Figs. 7 and 12). The $256 \mathrm{~m}$ long, NE striking GPR profile is surveyed across a topographic surface with ca. $12 \mathrm{~m}$ relief difference (Table 1) that increases toward the SW, especially at the end of the profile (Fig. 12). Near-surface sediments along the recorded GPR profile comprise Holocene redeposited brownish aeolian fine-grained sands and silty sands that, according to Hećimović (1987), reach ca. 2 m thickness. In the study area, Hećimović (1987) furthermore suggested that the stratigraphic footwall of Holocene deposits is composed of Late Pleistocene loess and loess-like deposits ca. $15 \mathrm{~m}$ in thickness.

The recorded $\mathrm{P} 3$ profile shows reflections dominantly parallel to the surface, with amplitudes identifiable down to the max. depth of $17 \mathrm{~m}$. The reflections are locally attenuated (between 90 and $140 \mathrm{~m}$ ), probably due to the higher water table. More importantly, there are areas where reflection facies are smeared and truncated, indicating tectonic deformation of the shallowest Quaternary deposits. Along the profile, seven fault strands were identified: F1and F2 in the first $20 \mathrm{~m}$ of the profile, F3 and F4 between 90 and $120 \mathrm{~m}$ of the profile and F5-F7 between 160 and $230 \mathrm{~m}$ of the profile (Fig. 12). These fault strands are interpreted as steep SW or NE dipping planes that dip at angles between 50 and $60^{\circ}$ and are characterized by both reverse and normal displacements (Fig. 12). The geometry of the reflectors indicates the presence of a vertical displacement of $<1 \mathrm{~m}$, how- ever, due to ambiguous reflector amplitude strengths in the hangingwall and footwall of interpreted fault strands, this displacement value should be treated with caution.

\section{GPR PROFILE P4}

In contrast to the other profiles surveyed, GPR profile P4 was recorded at an oblique angle to the NW striking Javorovac-Čepelovac Fault (Fig. 7). This profile orientation and location were selected due to dense vegetation cover and the terrain configuration (Fig. 7). Though the initial planned profile length was intended to intersect both faults, the presence of nearby houses and extensive vegetation cover resulted in a shorter, $318 \mathrm{~m}$ long, NW-SE striking profile recorded along the line with almost $28 \mathrm{~m}$ of elevation difference oblique to NW-SE striking Javorovac-Čepelovac Fault (Table 1 and Fig. 13). Surface sediments along the GPR profile are composed of Holocene redeposited brownish aeolian silty sands and clay-rich silts ( $\geq 2 \mathrm{~m}$ ), which in their footwall are composed of thick Late Pleistocene loess and loess-like deposits ( $\leq 10 \mathrm{~m}$; see Galović et al., 1981 for details).

Along the recorded $\mathrm{P} 4$ profile, reflector patterns were identifiable down to the max. depth of $10 \mathrm{~m}$. Taking into account the reflector geometry, the reflection facies along the profile were subdivided into two groups (R1 and R2). The R1 reflection facies group comprises undisturbed subhorizontal reflections that follow the topographic surface, while the R2 reflection facies 


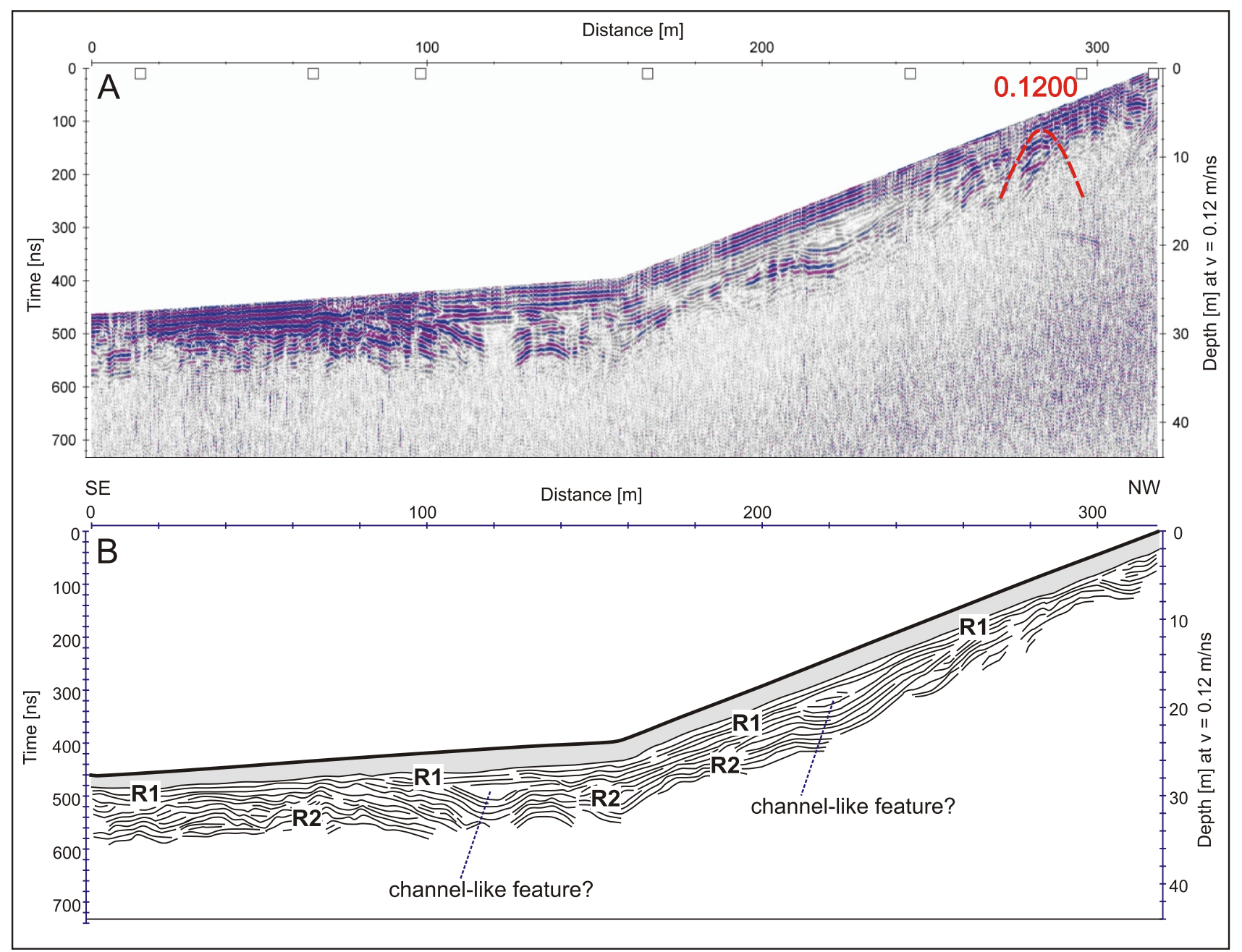

Fig. 13A - GPR profile P4 parallel to Javorovac-Čepelovac and Virje-Čepelovac faults; hyperbola with signal velocity of $0.12 \mathrm{~m} / \mathrm{ns}$ is indicated by the red curve; B - interpreted GPR profile P4; grey hatching is related to the zone influenced to direct wave; vertical exaggeration is ca. $2.6 \mathrm{x}$

group comprises underlying, deeper reflections characterized by apparently warped geometry. The warped reflection pattern that is especially pronounced between 100 and $140 \mathrm{~m}$, and 200 to $240 \mathrm{~m}$, of the surveyed GPR profile suggests a presence of two "channel-like" features (Fig. 13). Considering the fact that their recent topographic position show $\sim 10$ m elevation difference between the SE and NW part of the profile (Fig. 13), this could indicate that these "channel-like" features experienced differential uplift in very recent times. At the same time, fault strands were not identified along the profile line, probably due to the oblique profile orientation in relation to the Javorovac-Čepelovac Fault strike (Fig.13).

\section{GPR PROFILE P5}

The P5 profile was recorded in the northern limb of the $\mathrm{N}-\mathrm{S}$ striking Čurlovac-Veliko Trojstvo Fault (Fig. 7). Perpendicular to the fault plane, the $700 \mathrm{~m}$ long profile, with a recording azimuth towards the E, has $35 \mathrm{~m}$ of local relief (Table 1 and Fig. 14). The surface relief of the profile is characterized by gentle topography in its westernmost part that traverses into a steep, east-dipping slope going towards the east. Along the GPR profile, surface sediments are composed of Late Pleistocene loess and loess-like deposits, which, according to Korolija et al. (1986), reach $\leq 30 \mathrm{~m}$ of thickness. In the western portion of the GPR profile (Fig. 15), these sediments are altered by very recent stream incision and weathering, which yielded redeposited alluvial, lithologically similar, sandy and clay-rich silts.

The recorded P5 profile in this campaign is characterized by subhorizontal reflections that follow the orientation of the topographic surface. The penetration depth of the recorded profile was $<10 \mathrm{~m}$. Interpreted reflections have more or less consistent amplitude strengths and are often affected by the noise of adjacent power lines, buildings, trees and roads (Figs. 14 and 15). Along the surveyed profile, we were not able to interpret any visible fault strands, whereas the subsurface reflectors were laterally continuous without any pronounced vertical displacements.

\section{GPR PROFILE P6}

The P6 profile was recorded in the central portion of the NW-SE striking Mala Črešnjevica-Taborište Fault that is $\sim 8 \mathrm{~km}$ from the town of Pitomača (Fig. 7). The NE striking profile line is $492 \mathrm{~m}$ long and is recorded along a gentle topographic surface with a ca. $6 \mathrm{~m}$ elevation increase towards the SW (Table 1 and Fig. 16). Surface sediments along the recorded GPR profile are 


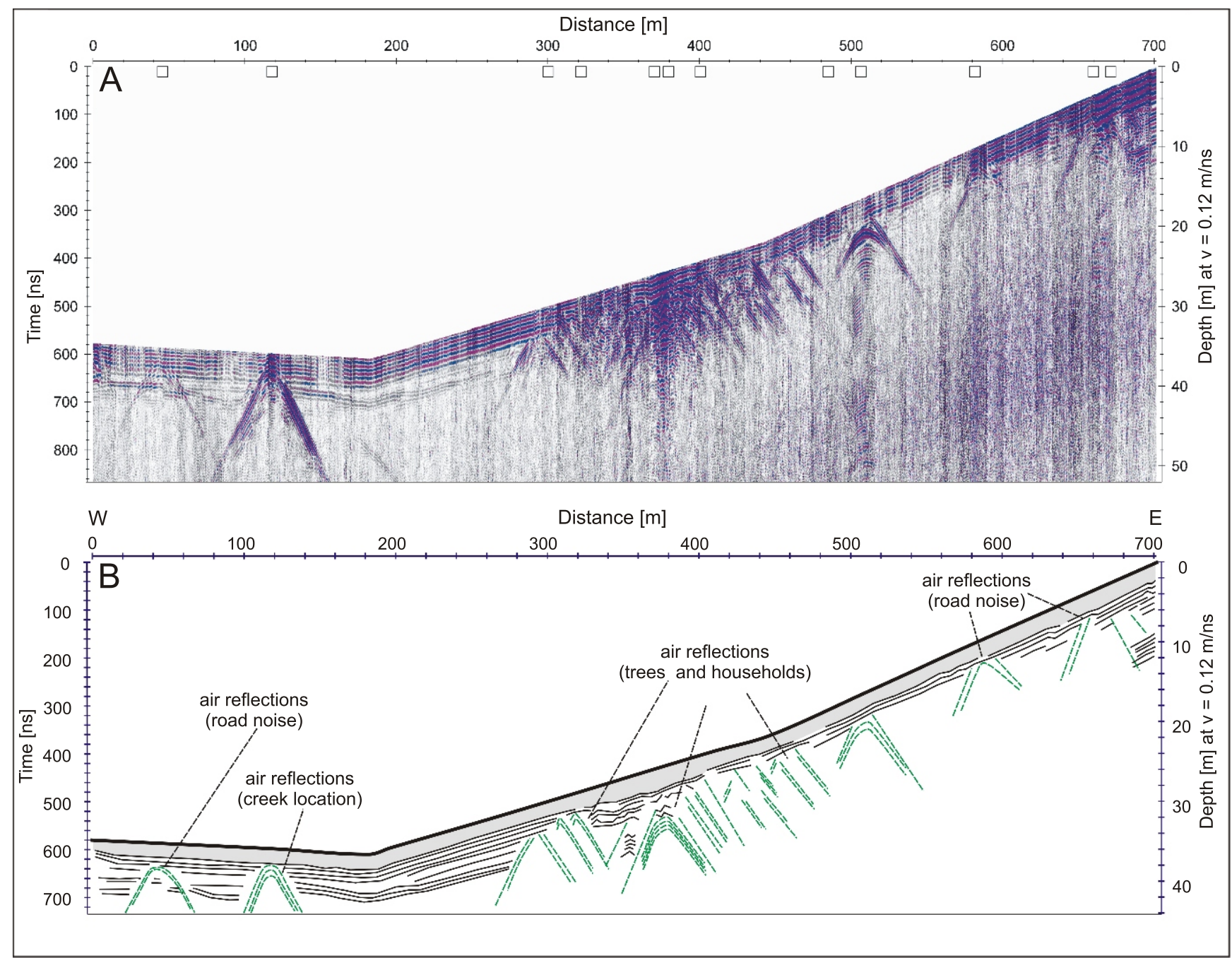

Fig. 14A - GPR profile P5 perpendicular to Čurlovac-Veliko Trojstvo fault; B - interpreted GPR profile P4; the profile is severely affected by air reflections that correlate with roads, streams, buildings, and dense vegetation cover; grey hatching depicts the zone of influence of direct waves; vertical exaggeration is ca. $5 \mathrm{x}$

composed of dominant Holocene brownish to greyish aeolian sands that, according to Galović et al. (1981), reach $\geq 9 \mathrm{~m}$ in thickness in this area.

The recorded P6 profile reflection pattern is characterized by moderate to high signal reflection strengths that are visible down to a depth of $14 \mathrm{~m}$. The reflections are parallel and consistent with the topographic relief, with only a few reflector truncations along the profile line (Fig. 16). These reflector truncations are associated with two fault pairs in the Mala Črešnjevica-Taborište Fault. The first pair is situated at the NE profile termination, between 20 and $40 \mathrm{~m}$, and the second pair at the SW end of the profile, between 430 and $490 \mathrm{~m}$ (Fig. 16). The fault strands (F1-F5) are identified by offset reflectors, inclined reflection facies, and low amplitude reflection contacts that often have ambiguous lateral continuation. The identified fault strand pairs with reverse vertical offsets indicate two pop-up (flower) structures that are also partly expressed in the surface topography. The topographic step along the profile line located between 430 and $480 \mathrm{~m}$ and poor reflector continuation between 410 and $430 \mathrm{~m}$ of the profile indicate a ca. $4 \mathrm{~m}$ recent uplift, accommodated along F3 (Fig. 16). Along the surveyed P6 profile, the identified fault strands are either SW or NE dipping planes with dip angles between 60 and $85^{\circ}$, which in addition to the reverse dip-slip motion probably reflect also its strike-slip component.

\section{DISCUSSION WITH CONCLUSIONS}

The identification of Quaternary active faulting in low deformation areas ( $<1 \mathrm{~mm} / \mathrm{yr})$ of temperate climate, such as that of Bilogora, is a challenging task, as the ongoing faulting is usually low-magnitude and significantly altered by recent landscape-forming processes (Alasset and Meghraoui, 2005). If faulting is present, the low deformation rates usually produce weak to moderate earthquakes, without co-seismic fault scarps and earthquake ruptures recognizable at the topographic surface (Alasset and Meghraoui, 2005; McCalpin, 2009; Jamšek Rupnik, 2013 and references therein).

In Bilogora, low deformation rates during the Quaternary (0.38 and $0.71 \mathrm{~mm} / \mathrm{yr}$; see Babić et al., 1978; Hećimović, 1987), and associated recent tectonic activity is shown by the numerous low magnitude earthquakes $(M \geq 5.6)$ clustered within the Kalnik-Koprivnica and Drava-Bilogora epicentral areas (Fig. 2) (Herak et al., 2009). Accordingly, those two seismogenic domains, characterized by multi-earthquake event records (Fig. 2 ), obviously indicate ongoing deformation in the Bilogora that may be associated to active faulting. In the work presented by Matoš (2014) and Matoš et al. (2016), recent tectonic activity in Bilogora is supported by DEM-based landscape analysis with 


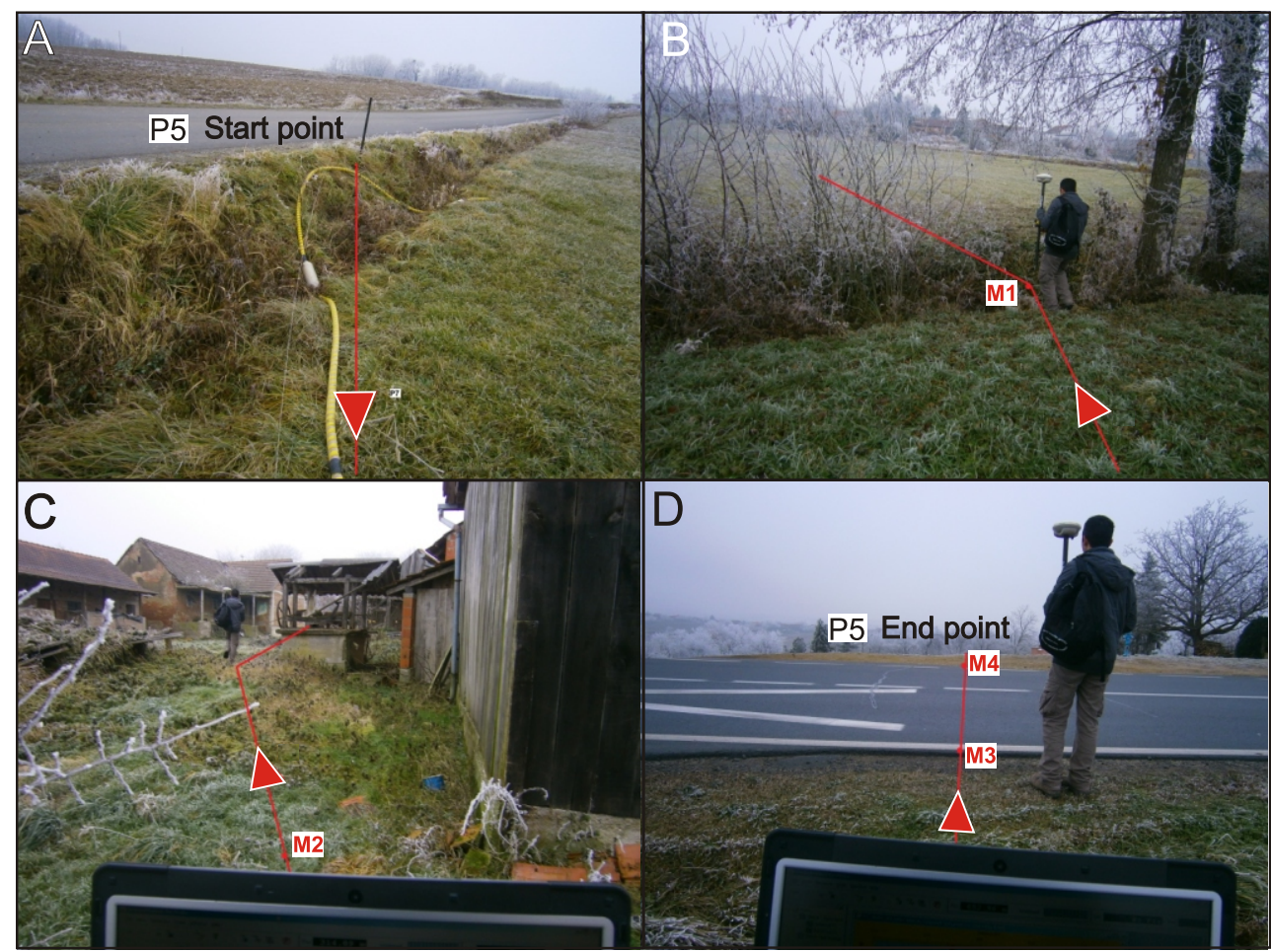

Fig. 15. GPR profile of more than $700 \mathrm{~m}$ recorded perpendicular to Čurlovac-Veliko Trojstvo Fault; M1 to M4 indicates "noise" locations along the recorded section; noise locations and associated air reflections correlates to roads and car noise (A, D), stream course with high vegetation (B) and constructed objects (C)

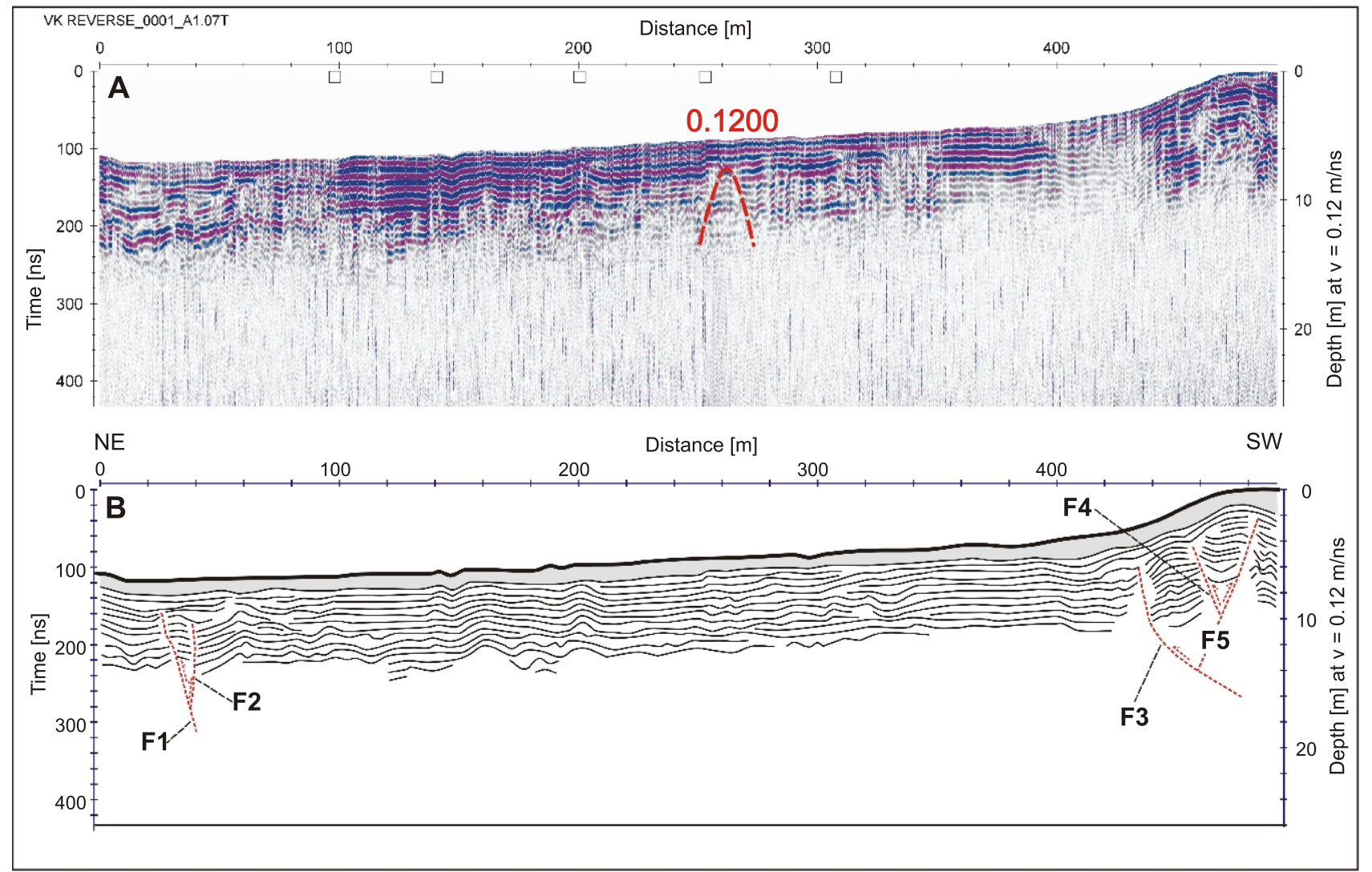

Fig.16A - GPR section P6 profile recorded perpendicular to Mala Črešnjevica-Taborište Fault; hyperbola with signal velocity of $0.12 \mathrm{~m} / \mathrm{ns}$ is indicated by the red curve; B - interpreted GPR profile P6; grey hatching is related to the zone influenced to direct wave; vertical exaggeration is ca. $5.4 \mathrm{x}$ 


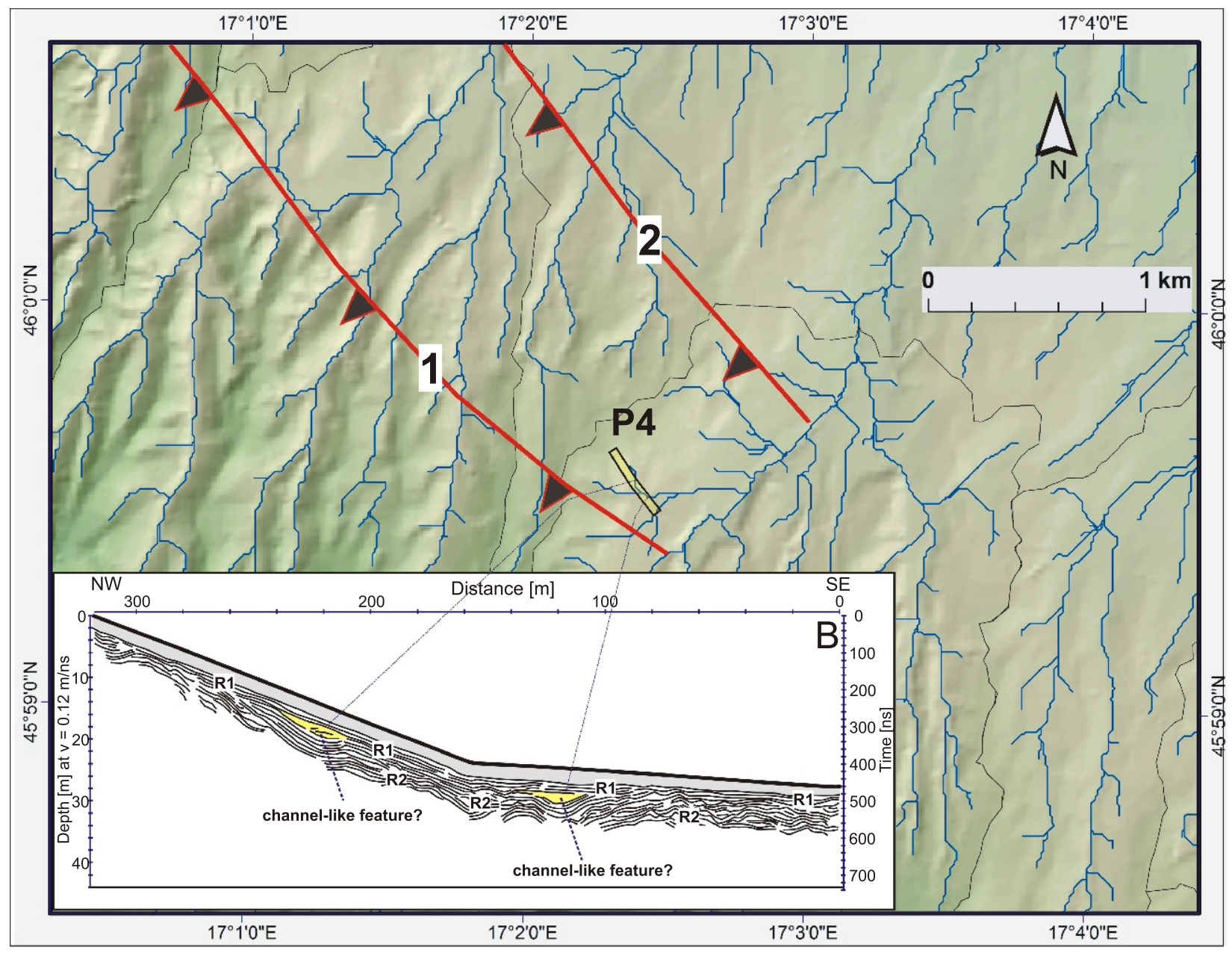

Fig. 17. DEM map and DEM-based drainage network around P4 GPR profile

Javorovac-Čepelovac and Virje-Čepelovac faults are indicated with numbers 1 and 2, respectively; note possible correlation between the two interpreted fluvial channels shown on the GPR profile and DEM-based drainage network; GPR profile P4 was surveyed oblique to the Javorovac-Čepelovac and Virje-Čepelovac faults; vertical exaggeration is ca. 2.6x

delineation of the morphometric parameters, and structural analysis of the 2D seismic sections in the wider Bilogora area (Fig. 5). Their results suggest that the landscape and landforms along the mapped Pliocene and Quaternary active faults in Bilogora can be considered to be rejuvenating the topographic surface (e.g., strongly dissected relief and landforms) due to tectonic deformation, which probably took place between 104 and 106 years (Matoš, 2014; Matoš et al., 2016).

The results presented in this work point to ongoing fault activity in the NW part of the study area (Fig. 5), where the landscape is also characterized by steep and strongly dissected slopes, short stream channels, and V-shaped gullies (Fig. 3). Though field structural evidence of vertical displacement of the youngest Quaternary deposits was not found, recent tectonics and near-surface strata deformation were recognized at several topographic scarps (see Figs. 11, 13 and 16) and multiple fault strands of reverse, normal and/or strike-slip kinematics. Vertical reflection displacements with magnitudes $\leq 1 \mathrm{~m}$ were identified on four GPR profiles located at the Subotica Podravska-Koprivnički Ivanec, Glogovac-Kalinovac, Virje-Čepelovac, and Mala Črešnjevica-Taborište faults (Figs. 10-12 and 16). Two GPR profiles, at the Javorovac-Čepelovac and Čurlovac-Veliko Trojstvo faults (Figs. 13 and 14), showed un- disturbed lateral continuation of reflectors, without any identified fault strands and vertical offsets that could be associated with Quaternary fault activity. In our opinion the latter results are probably due to unfavorable profile locations, not perpendicular to the fault strikes, severe noise, and signal attenuation that eventually caused poor profile resolution and limited depth of signal penetration (Figs. 13 and 14). Although the P4 profile, oblique to the NW striking Javorovac-Čepelovac Fault, did at first not show any reflector truncations and fault strands, after careful study it eventually revealed two locations of possible "channel-like" reflection features (Fig. 13). These two features were interpreted as two closely-spaced fluvial channels by analogy to a GPR profile measured along the Lourdes Fault in the western Pyrénées (Alasset and Meghraoui, 2005). This interpretation is supported by DEM-based reconstruction of a drainage network, which points to the possibility of existence of several fossil fluvial channels in the area (Fig. 17). If we consider that these "channel-like" features do indeed represent two Quaternary fluvial channels, the elevation difference and mutual channel positions may suggest recent tectonic uplift of ca. $10 \mathrm{~m}$ that was accommodated within the Javorovac-Čepelovac Fault Zone. 
Based on our results, we are of the opinion that the GPR survey carried out suggests near-surface strata deformation associated to recent fault activity in the area of Bilogora. Though the recent deformation rates in Bilogora have been rather low, the topographic scarps, numerous identified fault strands, and a vertical offset of the supposed palaeostream channels revealed by the GPR profiles demonstrate the applicability of the low-frequency GPR method in the identification of recent active faults. We believe that our preliminary results can be significantly improved by more extensive and detailed investigations in the future. Apart from detailed geomorphic mapping with the identification of fault-related landforms and of slope mass movements, multiple GPR profiling along selected fault traces would yield crucial information about the 3D structural geometry of near-surface faults. A combination of detailed geomorphic studies and multiple GPR profiles surveyed with electrical tomography and other seismic shallow surveys (e.g., refraction and reflection), similar to the procedures proposed by Jamšek Rupnik (2013) and Zajc (2015), would be the most appropriate methods for locating suitable palaeoseismological fault trenching sites. Fault trenching, combined with the analysis of seismic-related sedimentary features and its precise timing, will be an essential step in the assessment of the faults' seismogenic potential (McCalpin 2009). Accordingly, the proposed investigations will contribute to a better understanding and quantification of the seismogenic potential of the Quaternary active faults in Bilogora, and enable further insight into the probable seismic hazards and risks over a wider area.

Acknowledgements. The authors would like to thank Professor P. Aleksandrowski, Professor M. Jarosiński, Dr. L. Pospíšil, and Dr. A. Sobczyk for their very constructive remarks and comments that considerably improved the quality of this manuscript. We also acknowledge Croatian Oil Company INA-d.d. Zagreb for their provided seismic and well dataset and Schlumberger Company for their Petrel Seismic to Simulation software donation. This research was financially supported by the Ministry of Science, Education and Sports of the Republic of Croatia (Project CROTEC, grant no. 195-1951293-3155) and by the Slovenian Research Agency (Ph.D. Grant no. 1000-10-310074). This work also benefited from networking activities carried out within the EU-funded COST Action TU1208 "Civil Engineering Applications of Ground Penetrating Radar".

\section{REFERENCES}

Alasset, P.J., Meghraoui, M., 2005. Active faulting in the western Pyrénées (France) - paleoseismic evidence for late Holocene ruptures. Tectonophysics, 409: 39-54.

Anderson, K.B., Spotila, J.A., Hole, J.A., 2003. Application of geomorphic analysis and ground-penetrating radar to characterization of paleoseismic sites in dynamic alluvial environments: an example from southern California. Tectonophysics, 368: $25-32$.

Babić, Ž., Čakarun, I., Sokač, A., Mraz, V., 1978. Geology of the Quaternary deposits of Drava River (in Croatian). Geološki Vjesnik, 30: 43-61.

Bada, G., Horvath, F., Gerner, P., Fejes, I., 1999. Review of the present-day geodynamics of the Pannonian basin: progress and problems. Journal of Geodynamics, 27: 501-527.

Bada, G., Horváth, F., Dövényi, P., Szafián, P., Windhoffer, G. Cloetingh, S., 2007. Present-day stress field and tectonic inversion in the Pannonian basin. Global and Planetary Change, $\mathbf{5 8}$ 165-180.

Csontos, L., Vörös, A., 2004. Mesozoic plate tectonic reconstruction of the Carpathian region. Palaeoclimatology, Palaeoecology, Palaeogeography, 210: 156.

Crnko, J. (unpublished). Basic geological map of Kutina, M 1:100 000 (in Croatian). Geological Survey Zagreb, Zagreb.

Ferry, M., Meghraoui, M., Girard, J., Rockwell, T.K., Kozaci, O. Akyuz, S., Barka, A., 2004. Ground penetrating radar investigations along the North Anatolian fault near Izmit, Turkey: constraints on the rightlateral movement and slip history. Geology, 32: 85-88.

Fodor, L., Jelen, B., Márton, E., Skaberne, D., Čar, J., Vrabec, M., 1998. Miocene-Pliocene tectonic evolution of the Slovenian Periadriatic fault: implications of Alpine-Carpathian extrusion models. Tectonics, 17: 690-709.

Fodor, L., Bada, G., Csillag, G., Horváth, E., Ruszkiczay-Rüdiger, Z., Palotás, K., Síkhegyi, F., Timár, G., Cloetingh, S., Horváth, F., 2005. An outline of neotectonic structures and morphotectonics of the western and central Pannonian Basin. Tectonophysics, 410: 15-41.
Galović, I., Marković, S., 1979. Basic geological map of Virovitica M 1:100 000 (in Croatian). Geological Survey Zagreb, Federal Geological Institute, Beograd.

Galović, I., Marković, S., Magdalenić, Z., 1981. Explanatory notes for Basic geological map of Virovitica (1:100 000) (in Croatian). Federal Geological Institute, Beograd.

Grant, J.A., Schultz, P.H., 1996. Ground penetrating radar deployment in Argentine loess: implications for the character of the Martian stealth region. Lunar and Planetary Science, 27: 445-446.

Hećimović, I., 1986. Basic geological map of Đurđevac, $M$ 1:100000 (in Croatian). Geological Survey Zagreb, Federal Geological Institute Beograd.

Hećimović, I., 1987. Explanatory notes for geological map of Đurđevac (1:100 000) (in Croatian). Federal Geological Institute, Beograd.

Hećimović, I., 1995. Structure of the border area of Mt. Kalnik (in Croatian). Ph.D. thesis, University of Zagreb, Faculty of Mining, Geology and Petroleum Engineering, Zagreb.

Herak, D., Herak, M., Tomljenović, B., 2009. Seismicity and earthquake focal mechanisms in North-Western Croatia. Tectonophysics, 465: 212-220.

Horváth, F., Tari, G., 1999. IBS Pannonian Basin project: a review of the main results and their bearings on hydrocarbon exploration. Geological Society Special Publications, 156: 195-213.

Jamičić, D., Brkić, M., 1987. Basic geological map of Orahovica, M 1:100 000 (in Croatian). Geological Survey Zagreb, Federal Geological Institute, Beograd.

Jamičić, D., 1989. Basic geological map of Daruvar, M 1:100 000 (in Croatian). Geological Survey Zagreb, Federal Geological Institute, Beograd.

Jamšek, P., Benedetti, L., Bavec, M., Atanackov, J., Vrabec, M., Gosar, A., 2011a. Preliminary report on the Vodice fault activity and its potential for seismic hazard in the Ljubljana Basin, Slovenia. In: Proceedings: 2nd INQUA-IGCP-567 International Workshop on Active Tectonics, Earthquake Geology, Archaeology and Engineering, Corinth, Greece, 19-24 September 2011, (Proceedings volume 2, 2011: Earthquake Geology and Archae- 
ology: Science, Society and Critical Facilities) (ed. C. Grützner et al.): 96-98. Corinth, 2nd INQUA-IGCP-567, International Workshop.

Jamšek, P., Benedetti, L., Bavec, M., Atanackov, J., Gosar, A., Zajc, M., Vrabec, M., 2011b. Tectonic activity and seismogenic potential of the Vodice fault: surface and subsurface evidence. Geološki Zbornik, 21: 36-38.

Jamšek Rupnik, P., 2013. Geomorphological evidence of active tectonics in the Ljubljana basin. Ph.D. thesis, University of Ljubljana, Faculty of Natural Sciences and Engineering, Ljubljana.

Jarosiński, M., Beekman, F., Matenco, L., Cloetingh, S., 2011. Mechanics of basin inversion: finite element modeling of the Pannonian Basin System. Tectonophysics, 502: 121-145.

Jol, H.M., 2009. Ground Penetrating Radar: Theory and Applications. Elsevier Science, Amsterdam, Oxford.

Korolija, B., Crnko, J., 1985. Basic geological map of Bjelovar, M $1: 100000$ (in Croatian). Geological Survey Zagreb, Federal Geological Institute, Beograd.

Korolija, B., Vragović, M., Crnko, J., Mamužić, P., 1986. Explanatory notes for geological map of Bjelovar (1:100 000) (in Croatian). Federal Geological Institute, Beograd.

Kranjec, V., Prelogović, E., Hernitz, Z., Blašković, I., 1971. Lithofacies relations in late Neogene and Quaternary deposits in the area of Bilogora-Northern Croatia (in Croatian). Geološk Vjesnik, 24: 47-56.

Lenkey, L., Dövényi, P., Horváth, F., Cloetingh, S.A.P.L., 2002 Geothermic of the Pannonian basin and its bearing on the neotectonics. EGU Stephan Mueller Special Publication Series, 3: $29-40$.

Lučić, D., Saftić, B., Krizmanić, K., Prelogović, E., Britvić, V., Mesić, I., Tadej, J., 2001. The Neogene evolution and hydrocarbon potential of the Pannonian Basin in Croatia. Marine and Petroleum Geology, 18: 133-147.

Malå, 2009. Malå ProEx - Operating manual-Professional Explorer Control Unit. MALÅ Geoscience AB, Malå, Sweden.

Malvić, T., 2003. Oil-geological relations and probability of discovering new hydrocarbon reserves in the Bjelovar Sag (in Croatian). Ph.D. thesis, University of Zagreb, Faculty of Mining, Geology and Petroleum Engineering, Zagreb.

Malvić, T., Velić, J., 2011. Neogene tectonics in Croatian part of the Pannonian Basin and reflectance in hydrocarbon accumulations. In: New Frontiers in Tectonic Research-At the Midst of Plate Convergence (ed. U. Schattner): 215-238. InTech.

Marjanović, M., 2010. CROPOS-Croatian coordinate system (in Croatian), Ekscentar, 12: 28-34.

Marjanović, M., Link, H-P., 2011. CROPOS-Users' Manual. State Geodetic Administration (Republic of Croatia), Zagreb, Croatia: ISBN:978-953-293-100-6

Marković, S., 1985. Basic geological map of Podravska Slatina, M 1:100 000 (in Croatian). Geological Survey Zagreb, Federal Geological Institute, Beograd.

Marković, S., 1986. Explanatory notes for geological map of Podravska Slatina (1: 100 000) (in Croatian). Federal Geological Institute Beograd.

Matoš, B., 2014. Neotectonic and recently active faults in Bilogora Mountain area and assessment of their seismogenic potential (in English). Ph.D. thesis, University of Zagreb, Faculty of Mining, Geology and Petroleum Engineering, Zagreb.

Matoš, B., Tomljenović, B., Pérez-Peńa, J.V., 2016. Landscape response to recent tectonic deformation in the SW Pannonian Basin: evidence from DEM based morphometric analysis of Bilogora Mt. area, NE Croatia. Geomorphology, 263: 132-155.

McCalpin, J.P., ed., 2009. Paleoseismology. International Geophysics Series, 95, Burlington (MA), Academic Press, Elsevier.

McClymont, A.F., Green, A.G., Kaiser, A., Horstmeyer, H., Langridge, R., 2010. Shallow fault segmentation of the Alpine fault zone, New Zealand revealed from 2-D and 3-D GPR surveying. Journal of Applied Geophysics, 70: 343-354.
Meschede, M., Aspiron, U., Reicherter, K., 1997. Visualization of tectonic structures in shallow-depth high-resolution ground penetrating radar (GPR) profiles. Terra Nova, 9: 167-170.

Nagymarosy, A., Müller, P., 1988. Some aspects of Neogene biostratigraphy in the Pannonian Basin. AAPG Memoir, 45: 58-68.

Neal, A., 2004. Ground-penetrating radar and its use in sedimentology: principles, problems and progress. Earth-Science Reviews, 66: 261-330.

Patidar, A.K., Maurya, D.M., Thakkar, M.G., Chamayal, L.S. 2007. Fluvial geomporphology and neotectonic activity based on field and GPR data, Katrol hill range, Kachchh, Western India. Quaternary International, 159: 74-92.

Pikija, M., 1987. Basic geological map of Sisak, M 1:100 000 (in Croatian). Geological Survey Zagreb, Federal Geological Institute, Beograd

Prelogović, E., 1974. Neotectonic and structural relations in Drava region (in Croatian). Ph.D. thesis, University of Zagreb, Faculty of Mining, Geology and Petroleum Engineering, Zagreb.

Prelogović, E., Velić, J., 1988. Quaternary tectonic activity in the Western part of Drava Depression (in Croatian). Geološki Vjesnik, 41: 237-253.

Prelogović, E., Velić, J., 1992. Correlation of Quaternary sediments and tectonic activity of the eastern part of the Drava River Depression. Geologia Croatica, 45: 151-162.

Prelogović, E., Hernitz, Z., Blašković, I., 1969. Application of morphometric methods in solving structural and tectonic relations in Bilogora-Northern Croatia (in Croatian). Geološki Vjesnik, 22: 525-531.

Prelogović, E., Saftić, B., Kuk, V., Velić, J., Dragaš, M., Lučić, D., 1998. Tectonic activity in the Croatian part of the Pannonian basin. Tectonophysics, 297: 283-293.

Rashed, M., Kawamura, D., Nemoto, H., Miyata, T., Nakagawa, K., 2003. Ground penetrating radar investigations across the Uemachi fault, Osaka, Japan. Journal of Applied Geophysics, 53: $63-75$.

Ratschbacher, L., 1991. Lateral extrusion in the Eastern Alps, Part 1: Boundary conditions and experiments scaled for gravity, Part 1: Structural analysis. Tectonics, 10: 245-256.

Ratschbacher, L., Frisch, W., Linzer, H.-G., Merle, O., 1991. Lateral extrusion in the Eastern Alps, part 2: Structural analysis. Tectonics, 10: 257-271.

Rögl, F., 1999. Mediterranean and Paratethys. Facts and hypotheses of an Oligocene to Miocene paleogeography (short overview). Geologica Carpathica, 50: 339-349.

Royden, L.H., Horváth, F., eds., 1988. The Pannonian Basin - a study in basin evolution. AAPG Memoir, 45.

Saftić, B., Velić, J., Sztanó, O., Juhász, G., Ivković, Ž., 2003. Tertiary subsurface facies, source rocks and hydrocarbon reservoirs in the SW part of the Pannonian Basin (Northern Croatia and South-Western Hungary). Geologia Croatica, 56: 101-122.

Sandmeier, K.J., 2011. REFLEXW Version 6.0, Windows $9 x / N T / 2000 / X P / 7$. Program for the processing of seismic, acoustic or electromagnetic reflection, refraction and transmission data. Software Manual, Karlsruhe, Germany.

Steininger, F.F., Wessely, G., 1999. From the Tethyan Ocean to the Paratethys Sea: Oligocene to Neogene stratigraphy, paleogeography and paleobiogeography of the circum-Mediterranean region and the Oligocene to Neogene basin evolution in Austria. Mitteilungen der Österreichischen Geologischen Gesellschaft, 92: 95-116.

Šimunić, A., Hećimović, I., Avanić, R., 1994. Basic geological map of Koprivnica, M 1:100 000 (in Croatian). Geological Survey Zagreb, Zagreb.

Tari, V., Pamić, J., 1998. Geodynamic evolution of the northern Dinarides and the southern part of the Pannonian Basin. Tectonophysics, 297: 269-281.

Tari, G., Dövényi, P., Dunkl, I., Horváth, F., Lenkey, L., Stefanescu, M., Szafián, P., Tóth, T., 1999. Litosphere structure of the Pannonian basin derived from seismic, gravity and geo- 
thermal data. Geological Society Special Publications, 156: 215-250.

Tomljenović, B., Csontos, L., 2001. Neogene-Quaternary structures in the border zone between Alps, Dinarides and Pannonian Basin (Hrvatsko zagorje and Karlovac Basin, Croatia). International Journal of Earth Sciences (Geologische Rundschau), 90: 560-578.

Ustaszewski, K., Schmid, S.M., Fügenschuh, B., Tischler, M., Kissling, E., Spakman, W., 2008. A map-view restoration of the Alpine-Carpathian-Dinaridic system for Early Miocene. Swiss Journal of Geosciences, 101 (Supplement 1): 273-294.

Velić, J., Weisser, M., Saftić, B., Vrbanac, B., Ivković, Ž., 2002. Petroleum-geological characteristics and exploration level of the three Neogene depositional megacycles in the Croatian part of the Pannonian basin. Nafta, 53: 239-249.
Zajc, M., 2015. Optimization of Low-Frequency Ground Penetrating Radar surveys for the characterization of shallow geological structures (in Slovenian). Ph.D. thesis, University of Ljubljana, Faculty of Civil and Geodetic Engineering, Ljubljana.

Zajc, M., Pogačnik, Ž., Gosar, A., 2014. Ground penetrating radar and structural geological mapping investigation of karst and tectonic features in flyschoid rocks as geological hazard for exploitation. International Journal of Rock Mechanics and Mining Sciences, 67: 78-87.

Zajc, M., Celarc, B., Gosar, A., 2015. Structural-geological and karst feature investigations of the limestone-flysch thrust-fault contact using low-frequency ground penetrating radar (Adria-Dinarides thrust zone, SW Slovenia). Environmental Earth Sciences, 73: 8237-8249. 